\title{
China's quest for oil security: oil (wars) in the pipeline?
}

\author{
Pak K. Lee
}

\begin{abstract}
China's rapidly expanding demand for crude oil in the 1990s has brought about debates about the potential impact of the energy challenges facing China. Within the country, energy as a security issue has seized the attention of its leaders. Outside China, international strategic thinkers have been arguing among themselves over how China's thirst for oil would impact on regional peace and stability.

This paper sets out to examine the following questions: How and why has the basic need for crude oil been perceived as a security question in China? How does China enhance its oil security? Is the option to engage Russia and Central Asia viable and why? What are the possible impacts of China's oil diplomacy on regional security and stability? It concludes that the oil diplomacy with Kazakhstan and Russia is far from promising. In the short run, China has to rely on the oil in the Middle East and to exploit the resource in its offshore areas in the medium to long term. This may lead to festering relations with Russia, the US, Japan, India and the Southeast Asian nations. The growing presence of China in the Persian Gulf and East and South China Sea gives cause for concern to the US, Japan, India and the Southeast Asian states.
\end{abstract}

Keywords Oil security; Nakhodka, Daqing, Japan, Kazakhstan, American containment of China.

\section{Introduction}

All modern industrial countries are concerned about the security of the supplies of vital non-renewable resources. Oil falls into this strategic category of vital materials (Klare 2001). China, as a relatively late industrializing country, did not pay serious attention to energy security in general, and oil security in particular, until 1993 when it became a net oil-importing country.

Pak K. Lee is Assistant Professor and Leader of the Public Administration and Liberal Studies programmes in the School of Arts and Social Sciences at the Open University of Hong Kong. His research interests include non-traditional security issues in China and the political economy of China's economic reforms, especially about central-local tax reforms.

Address: Pak K. Lee, School of Arts and Social Sciences, The Open University of Hong Kong, 30 Good Shepherd Street, Homantin, Kowloon, Hong Kong, SAR. E-mail: pklee@ouhk.edu.hk

The Pacific Review

ISSN 0951-2748 print/ISSN 1470-1332 online (C) 2005 Taylor \& Francis Group Ltd

http://www.tandf.co.uk/journals

DOI: $10.1080 / 09512740500162949$ 
According to the International Energy Agency (IEA), China has overtaken Japan as the second-largest global consumer of crude oil after the United States. It is predicted that by 2030 China's net oil imports will account for more than 80 per cent of its total oil consumption (Mallet 2004). ${ }^{1}$

This paper examines China's quest for oil security since the early 1990s. Questions to be asked are: Why does China care about oil security? How does China adapt to becoming increasingly dependent on imported oil? What is China's strategy to strengthen its oil security or to reduce its exposure to potential supply disruptions and sudden price rises? And, more importantly, would China's policy of enhancing oil security strain its relationships with its neighbouring countries as well as the United States?

Before dealing with Chinese attempts to enhance its oil security, the concepts of security and energy security are to be addressed. States are said to seek to reduce their insecurity either by reducing their vulnerability or by preventing or lessening threats (Buzan 1991: 112).

Conventionally economic security is concerned with 'the degree to which national security is threatened by dependence on external sources of technology, raw materials, food and fuel' (Cable 1995: 313). Seen in this perspective, traditional energy security concern is about the supply of and demand for energy (Stares 2000). One of the standard definitions of energy security is that it is

A state in which consumers and their governments believe, and have reason to believe, that there are adequate reserves and production and distribution facilities available to meet their requirements in the foreseeable future, from sources at home or abroad, at costs which do not put them at a competitive disadvantage or otherwise threaten their well-being.

(Belgrave et al. 1987: 2) $)^{2}$

A state is said to be insecure if it has to rely on external sources of strategic materials which contribute to its 'war potential' or if the supply of the strategic materials is under threat. In essence, energy security is about the 'security of supply' and the 'stability of price' if reliance on external sources becomes inevitable.

The rest of this paper consists of three major sections. The first deals with the question why China began to be concerned about oil security in the early 1990s. The next section discusses in detail the strategy by which China pursues its oil security, focusing on how China diversifies its oil import channels into Kazakhstan in Central Asia and Russia. The third section is devoted to exploring the implications of China's quest for oil security on regional security and stability. Possible developments of its relations with the major powers of Russia, Japan and India, as well as the United States and with middle-power nations in Southeast Asia will be discussed. 


\section{China's concern about oil security}

With the operation of the Daqing oilfield in Heilongiiang in 1964 and of the Shengli oilfield in Shandong in subsequent years, China had achieved selfsufficiency in oil consumption in the period 1965-73; it had generated a surplus for export since 1973 (Cheng 1982: 460). ${ }^{3}$ China, however, began to pay serious attention to oil security in 1993 when it became a net oil-importing country. In the year China's net imports of oil - crude and product oil imports minus crude and product oil exports - amounted to 8.57 million tonnes. Since then China has become increasingly dependent on oil imports. The net imports increased sharply to 71.41 million tonnes, meeting 28.8 per cent of China's domestic consumption of oil, in 2002. In contrast, the ratio was only 5.8 per cent in $1993 .{ }^{4}$

The increasing dependence on foreign sources of oil is attributable to the sluggish growth of domestic production of oil and the rapidly rising consumption of the resource in the country. Although domestic output of crude oil rose to 160.74 million tonnes in 1997 from 138.31 million in 1990, since 1997 the production has stagnated in the range between 160 and 170 million tonnes per annum. The largest Daqing oilfield began to reduce production in 2003, with the annual output falling below 50 million tonnes in the year (Liaowang dongfang zhoukan [Beijing], April 1, 2004: 44-6). ${ }^{5}$ At the same time, however, the spread of industrialization, the growth of population and the remarkable growth of personal wealth have produced a huge demand for automobiles, home appliances and other consumer goods. China's consumption of oil therefore rose rapidly to 275.2 million tonnes in 2003 from 140.5 million tonnes in 1993. The increase in 2003, a rise of 11.5 per cent over 2002, was particularly striking. Chinese crude imports in 2004 soared 35 per cent to 120 million tonnes. It was predicted in early 2005 that the imports in 2005 would rise 18 per cent to 142 million tonnes (SCMP 2005b; see Table 1). China's domestic estimates of its gaps in oil production and consumption also indicate that the annual deficit in oil supplies would increase to 197 million tonnes in 2015 and 250 million tonnes five years later (Wen Wei Po [Hong Kong], July 28, 2004: A6; 21 shiji jingji baodao [Guangzhou], September 2, 2004: 3; see Table 2 for an estimate made by the US Energy Information Agency). The inevitable reliance on imported oil has renewed Chinese long-standing concerns about energy security. Oil has become a source of vulnerability for China.

The sharp rise in crude oil price in 1999-2000 also led China to care about its oil security. At the beginning of 1999, the benchmark Brent crude oil price stood at only US $\$ 10.44$ per barrel. The price had more than doubled to US $\$ 25.10$ one year later at the beginning of 2000 and stayed at US $\$ 22.50$ when the year 2001 started. ${ }^{6}$ Analysts were warning of a third oil crisis, after that of 1973 and 1979 (Salameh 2001). There were three reasons for the buoyant oil prices: Asia's swift economic recovery from its financial crisis of 1997-98; the decision in March 1999 by the Organization of Petroleum 
Table 1 China's production and consumption of oil (unit: million tonnes per year)

\begin{tabular}{cccc}
\hline Year & Production & Consumption & $\begin{array}{c}\text { Production/ } \\
\text { consumption }(\%)\end{array}$ \\
\hline 1992 & 142.0 & 129.0 & 110.08 \\
1993 & 144.0 & 140.5 & 102.49 \\
1994 & 146.1 & 149.5 & 97.73 \\
1995 & 149.0 & 160.7 & 92.72 \\
1996 & 158.5 & 174.4 & 90.88 \\
1997 & 160.1 & 185.6 & 86.26 \\
1998 & 160.2 & 190.3 & 84.18 \\
1999 & 160.2 & 207.2 & 77.32 \\
2000 & 162.6 & 230.1 & 70.66 \\
2001 & 164.8 & 232.2 & 70.97 \\
2002 & 168.9 & 245.7 & 68.74 \\
2003 & 169.3 & 275.2 & 61.52 \\
\hline
\end{tabular}

Source: British Petroleum (2004: 7, 10).

Exporting Countries (OPEC) to reduce production; and the tightening of the global oil market as a result of little OPEC spare capacity (FEER 2000: 48; Salameh 2001). The immediate effect of the price hike for China was a sharp rise in the net imports of oil in pecuniary terms in 1999 and 2000. China's net imports of oil soared from US $\$ 1.75$ billion in 1998 to US $\$ 3.88$ billion in 1999 and US $\$ 12.73$ billion the following year. Since then the annual oil import bills have exceeded US $\$ 10$ billion (see Table 3 ).

Brent oil prices averaged US $\$ 25.02$ per barrel in 2002 and US $\$ 28.83$ per barrel in 2003. Given that OPEC intends to keep the crude-oil prices within the target range of US $\$ 22-28$ a barrel by controlling the production of the

Table 2 China's oil consumption and production capacity, 1990-2025 (million barrels per day)

\begin{tabular}{lcccccccc}
\hline & \multicolumn{3}{c}{ History } & & \multicolumn{5}{c}{ Projections } \\
\cline { 2 - 4 } \cline { 7 - 9 } & 1990 & 2000 & 2001 & & 2010 & 2015 & 2020 & 2025 \\
\hline Production capacity & 2.8 & N/A & 3.3 & & 3.6 & 3.5 & 3.5 & 3.4 \\
Consumption & 2.3 & 4.8 & 5.0 & & 7.6 & 9.2 & 11.0 & 12.8 \\
$\begin{array}{l}\text { How much can China } \\
\text { produce the oil it }\end{array}$ & 121.74 & N/A & 66.00 & & 43.37 & 38.04 & 31.82 & 26.56 \\
consumes? (\%) & & & & & & & \\
\hline
\end{tabular}

Note: n.a.: Not available.

Source: US Department of Energy, Energy Information Administration (2004) International Energy Outlook 2004, Washington, DC: DoE/EIA; available at http://www.eia.doe.gov/ oiaf/ieo/pdf/appa1_a8.pdf and http://www.eia.doe.gov/oiaf/ieo/pdf/appd1_d6.pdf (accessed September 11, 2004). 
Table 3 China's imports and exports of crude oil (unit: US\$ million)

\begin{tabular}{cccr}
\hline Year & Imports & Exports & Net imports \\
\hline 1993 & $2,323.41$ & $2,390.03$ & -66.62 \\
1994 & $1,573.40$ & $2,080.99$ & -507.59 \\
1995 & $2,356.43$ & $2,064.21$ & 292.22 \\
1996 & $3,406.55$ & $2,777.20$ & 629.35 \\
1997 & $5,456.21$ & $2,734.13$ & $2,722.08$ \\
1998 & $3,274.54$ & $1,527.45$ & $1,747.09$ \\
1999 & $4,641.24$ & 765.28 & $3,875.96$ \\
2000 & $14,860.66$ & $2,128.01$ & $12,732.65$ \\
2001 & $11,666.45$ & $1,385.37$ & $10,281.08$ \\
2002 & $12,757.34$ & $1,232.49$ & $11,524.85$ \\
2003 & $19,808.73$ & $1,661.22$ & $18,147.51$ \\
\hline
\end{tabular}

Sources: China Commerce Yearbook (formerly known as Yearbook of China's Foreign Economic Relations and Trade between 2001 and 2003, or Almanac of China's Foreign Economic Relations and Trade between 1988 and 2000), various years.

cartel, the possibilities of disruptions in oil production in Iraq, Africa and Russia, and the rapid growth of oil demand by such populous countries as China and India, it is very unlikely that the oil price would fall below the low levels in $1998 .^{7}$ Among oil-importing countries, China is particularly vulnerable to sustained high oil prices for two reasons. One is its high oil intensity. China is a heavily oil-intensive economy, consuming 1.56 million barrels per US $\$ 1$ billion of gross domestic product (measured in 1996 US dollars) in 2003, nearly twice the world average. This is due to inefficiency in the production and consumption of oil in the country (Economist Intelligence Unit 2004c). Another challenge facing China is that it would have to import an increasing amount of oil at relatively high prices. With a currency peg to the US dollar, in which global crude oil is traded, China suffers more than Japan and Europe from the rising oil price (Economist Newspaper 2004a).

These unfavourable developments led Hu Jintao, the general secretary of the ruling Chinese Communist Party and State President, to emphatically single out oil as an area of concern in a central economic work conference in late November 2003, articulating it in security terms (Liaowang dongfang zhoukan, July 15, 2004: 60-1).

\section{China's quest for oil security}

This section focuses on the means by which China pursues energy, particularly oil, security. In short, China's strategy of oil security is built on the premise of minimizing its vulnerability to American power.

One obvious route in its search for oil security China has been taking since 1993 is to diversify oil supplies into a variety of countries in the Middle East, 
West Africa and Southeast Asia. In 1993 when China shifted to become a net importer of oil, the four biggest suppliers of oil to China - Oman, Indonesia, Yemen and Angola - shipped 70 per cent of China's imports to the country. As a result of the drive for diversification of import sources, China's oil trade has been pushed towards the Middle East, in addition to the traditional partners in Southeast Asia and Africa. Consequently, the top six principal suppliers in 2003 - Saudi Arabia, Iran, Angola, Oman, Yemen and Sudan - provided China with almost two-thirds of what it bought overseas. ${ }^{8}$

The events of September 11, 2001, and George W. Bush's subsequent military action against Saddam Hussein triggered a reassessment on the part of China on its oil security policy. Soon after the terrorist attacks, the United States has been keen to station marine troops along the Strait of Malacca to combat transnational terrorist threats. Oil facilities in Saudi Arabia have become likely targets of al-Qaeda terrorist strikes since a wave of violent attacks began in May 2003. Suicide bombings in the kingdom sharpen concerns over political stability of the Saudi regime as well as Middle Eastern oil supply security in particular. Moreover, terrorism in Iraq and Saudi Arabia have inhibited oil exploration and development in the Middle East (Huband and Wallis 2004; Klare 2004, 84-94). ${ }^{9}$ With an aim to reduce its reliance on Arab oil supplies, which have to be shipped via the Indian Ocean, the Strait of Malacca and the South China Sea to China, China endeavours to strengthen its presence in Central Asia and Russia. ${ }^{10}$

Although Kazakhstan and Russia were not principal oil suppliers to China in 2003 (and before), oil diplomacy with them forms the central plank of China's oil security strategy. ${ }^{11}$ The primary advantage of exploration in Central Asia and Russia is that both the oil resource there and the overland pipeline are not subject to US domination. Signs indicate that China is concerned about whether it could stem the US from imposing serious constraints on its striving for reunification with Taiwan. China is worried that in the event of a Sino-American confrontation over Taiwan, the US would disrupt or even block the shipment of oil to China from the Middle East via the Strait of Malacca in Southeast Asia. ${ }^{12}$ We shall return to this issue later. Another attraction is that the Russian oil shipped through the pipeline would feed into the existing infrastructure in Daqing oilfields, generating enough profits for China National Petroleum Corporation (CNPC) and maintaining employment opportunities there (Andrews-Speed et al. 2002: 64; Downs 2004: 31-2).

\section{Oil diplomacy in Kazakhstan}

China began to construct ties with the newly independent Central Asian states in the wake of the break-up of the Soviet Union in 1991. In 1994 China expressed its interests to explore and develop oil resources in Kazakhstan when Li Peng visited the country. In June 1997, CNPC, created from the 
Ministry of Petroleum Industry in 1988, acquired a 60 per cent share in Kazakhstan's Aktobemunaigaz oil company, which developed oilfields in Aktyubinsk region, for US $\$ 4.3$ billion. The Kazakh company controls three large oilfields in northwestern Kazakhstan with combined reserves of 1 billion barrels. Three months later, CNPC won a controlling interest in Uzen, the second largest oilfield in Kazakhstan (Downs 2000: 15-16). In May 1998 the two countries reached an agreement to construct a 3,000-km oil pipeline linking the Kazakh oilfields with China's Xinjiang province (Gill and Oresman 2003: 24). China also engaged in talks with Turkmenistan in August 1998 about oil and gas projects. These included a pipeline to export oil and gas from the Central Asian country to China (BBC News 1998a, 1998b; Wu and Fesharaki 2002). However, the prohibitive cost of building the pipeline, the worry about insufficient reserves in the oilfields in Uzen and Aktyubinsk and the fall of international oil prices in 1997 combined to force the Chinese to shelve the project in July 1999. The oil produced in Kazakhstan was not imported direct into China. Instead, it was refined by regional refiners and swapped for Persian Gulf oil (Andrews-Speed et al. 2002, 60; BBC News 1999; Downs 2000: 28; Jaffe and Lewis 2002; OGJ 1999).

China rekindled its interest in Central Asia after September 2001. Since then, the Chinese government has been concerned about US military expansion into Central Asia. The increasingly powerful presence of the US in the region, Chinese security analysts believe, would enable the US to extend its control over oil from the Middle East to Central Asia, and hence would have an adverse impact on China's oil as well as national security. China harbours suspicion that the US has a dual political agenda in the region to contain China and Russia and to fight against terrorism (Starobin et al. 2002). CNPC and KazMunaiGaz, Kazakh state oil corporation, began in May 2002 working on a 449-km pipeline running from Kenkiyak in central Kazakhstan to the Caspian oil terminal Atyrau, which was commonly considered the first section of the cross-country pipeline. It was completed in March 2003 (Gill and Oresman 2003: 24). In the same month, each of China National Offshore Oil Corporation Ltd (CNOOC Ltd) and China Petrochemical Corporation (Sinopec Group) agreed to pay US\$615 million to buy an 8.33 per cent stake in the North Caspian Sea Project from the British Gas Group. Located in westernmost Kazakhstan, the oilfields rank among the world's largest for the past thirty years, with recoverable reserves estimated up to 13 billion barrels. Sinopec expected that the production would peak in seven to eight years, and steady output would be sustained for twenty years. With much optimism of the purchase notwithstanding, the attempts to invest in the oilfields were, however, blocked in May 2003 by Royal Dutch/Shell and its partners in the project (Bradsher 2003a, 2003b; Chan 2003; Galloway 2003; Ng 2003a; Pala and Bradsher 2003; Saigol and Roberts 2003; Xie 2003).

This unexpected setback prompted Chinese high-level contacts with the Kazakh government. During Hu Jintao's state visit to Kazakhstan in June 2003, the two countries reached an agreement to reactivate the plan for 
building the oil pipeline that was shelved in 1999. CNPC bought the remaining stake of a Sino-Kazakh oil joint venture for US $\$ 150$ million shortly after Hu's trip. Upon completion of the acquisition, CNPC would wholly own Aktobemunaigaz, which produced more than 4.3 million tonnes (31.52 million barrels) of oil in 2002 (Interfax Information Services 2003; Ng 2003b).

Almost immediately after the Russian decision to postpone the construction of an oil pipeline linking eastern Siberia to China's Daqing (to be discussed later), China speeded up negotiating with Kazakhstan to revive the pipeline project. The possibilities of building a $988-\mathrm{km}$ pipeline that would run from eastern Kazakhstan's Atasu to Alashankou (or Dzungarian Gate) on the border between the two countries, or the second section of the pipeline, was discussed when Kazakh Prime Minister Daniel Akhmetov visited China in September 2003. With a pipeline from Alashankou to the refineries in Dushanzi, Xinjiang, the 1,300-km pipeline, if completed, would deliver up to 20 million tonnes of oil to China annually in or around 2010. The presidents of the two countries signed in May 2004 in Beijing a joint declaration on the construction of the Atasu-Alashankou pipeline. At an estimated cost of US $\$ 700-850$ million, construction started in late September 2004 and would be completed by the end of 2005 . This section would be likely to stretch west across Kazakhstan for $1,340 \mathrm{~km}$ (i.e. section III) to connect with the Kenkiyak-Atyrau pipeline via Kumkol oilfields. This threesection pipeline as a whole would extend $3,088 \mathrm{~km}$ (Huanqiu shibao, Beijing September 19, 2003: 16; 21 shiji jingji baodao, September 29, 2003, 6; Mai 2003a; Roberts 2004). In addition, CNPC purchased in August and October 2003 from Saudi Arabia's Nimir Petroleum and ChevronTexaco respectively their stakes in Texaco North Buzachi. The latter was operating the North Buzachi oil and gas field in northwest Kazakhstan, which was estimated to have oil of 1.5 billion barrels (21 shiji jingji baodao, October 30, 2003: 1, 3; Platts 2003c).

Yet, there is still a missing link between the completed first section of the pipeline and the second section under construction. The two governments have yet to study the third section, or the middle section geographically. Financing is obviously a hurdle (Roberts 2004). Without this 'missing link', Caspian oil cannot be delivered to the Chinese market. Second, the two countries have yet to settle on a price for the Kazakh oil flowed through the pipeline (Economist Intelligence Unit 2004b). Third, what China wishes to import from Kazakhstan is much more than the latter can afford. In February 2003 CNPC told Kazakh officials that China would need up to 50 million tonnes per year. This was 3 million tonnes more than Kazakhstan's entire oil output in 2002 (Roberts 2003). ${ }^{13}$ Fourth, to fully utilize the oil imported from Kazakhstan, the oil has to be refined and then delivered through China's domestic pipelines to the major consumer markets along the coast in the east. It is open to debate as to whether it makes sense economically to construct a full pipeline system. Given that the two countries have been negotiating the pipeline for a decade, if China had found the project commercially viable, 


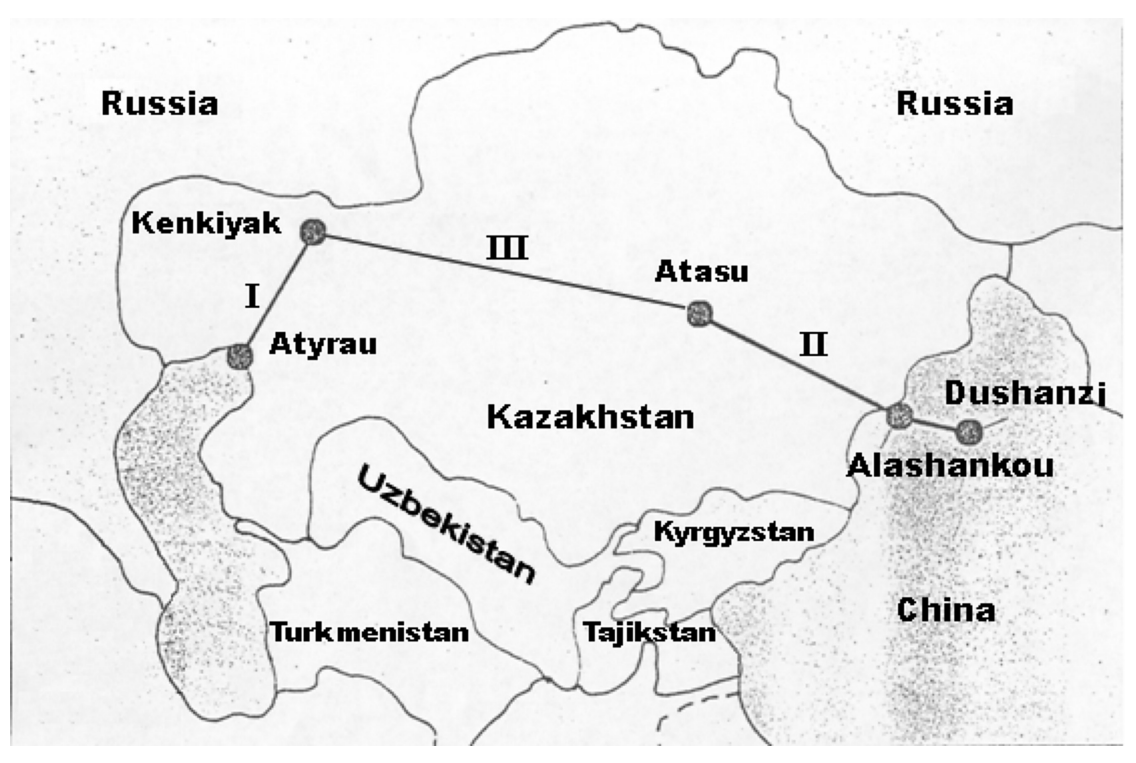

Map 1 Sino-Kazakh oil pipeline

Source: Adapted from Shijie zishi, July 16, 2004, p. 54.

the pipeline would have been built and in operation. Oil industry executives in the West have argued that China has overpaid for its oil assets in the Central Asian country (Kynge 2004). Some rather viewed the construction of the second section of the pipeline as a bargaining chip for Premier Wen Jiabao to make a last-ditch effort to persuade Moscow on the routeing of the Russian Far East pipeline when he visited Russia in September 2004 (WSJ 2004). Fifth, with the influence of its political and military power in Central Asia, the US has pushed ahead with its favoured Baku-TbilisiCeyhan route (BTC pipeline) that would enable Central Asian countries to export its oil and gas to Europe via Turkey. China therefore suspects that the US exerts pressure on international financial institutions not to finance the construction of the Kazakh-Chinese pipeline (Becker 2001; Liaowang [Beijing], April 29, 2002: 57-9; Lam 2001; Huanqiu shibao, May 21, 2004: 3; Shijie zhishi [Beijing], July 16, 2004: 54-5). Given that almost all of Kazakh oil exports are transported to world markets via Russia (either northwards to Russia's Samara or westwards via the new Caspian Pipeline Consortium line from Tengiz to Novorossiysk on the Black Sea), Kazakhstan is increasingly interested in exporting its oil resources via the BTC pipeline so as to be more independent from Moscow in its oil exports. Moreover, seen from a geographical perspective, the Chinese investment in Kazakh oilfields concentrates in the west of the country and the most advantageous route for exporting Kazakh oil is to go via Iran in the south. Kazakh President Nursultan 
Nazarbayev had urged the George W. Bush administration to consider Iran as a route to send some of his country's oil to the international market (Tyler 2001). It is doubtful whether the less economically feasible, lengthy KazakhChinese pipeline could be completed according to the planned schedule. The prospects of Sino-Kazakh energy cooperation would be more promising if Kazakhstan and Russia established a joint, eastbound oil export line. However, the two countries had not yet discussed the cooperative project (Gorst 2003d; Solovyov 2003). Finally, the prospects for Central Asian trade with China are also clouded by suspicions that China is a 'hegemon in waiting'. Central Asians are fearful of Chinese expansionism, notably its illegal migration to their countries (quoted from Gill and Oresman 2003: 38; Bransten and Lelyveld 2004). ${ }^{14}$

\section{Engaging Russia}

The Chinese effort to engage Russia in energy trade also commenced as early as 1994 when China expressed that it would develop a pipeline from the Kovykta gasfields near Irkutsk (Andrews-Speed et al. 2002: 62). In the same year, the Russian government proposed building an oil pipeline linking the two countries. ${ }^{15}$ Two routes of Sino-Russian pipeline had been considered. Russia favoured the one that would go from eastern Siberia, across Mongolia, into Beijing because of a shorter distance. China's preference was to circumvent Mongolia for security reasons (OGJ 2000). During a SinoRussian summit in July 2001, the two countries reached an agreement calling for formulating a plan for constructing a long-discussed US \$1.7-1.8 billion oil pipeline from Angarsk (also near Irkutsk) in eastern Siberia to Daqing in Heilongjiang province. It was expected that the 2,400-km pipeline - the Daqing line - could be completed as early as 2005 and that an annual initial throughput of as many as 20 million tonnes (147 million barrels) would be shipped to China (Downs 2000: 28-9; Jaffe and Lewis 2002; SCMP 2001a, 2001b; Wen Wei Po, September 28, 2001: A2). In contrast, China imported no more than 1.4 million tonnes of oil from Russia in 2002 (Huanqiu shibao, December 19, 2002: 16). Nonetheless, major oil deposits in Siberia are remote from the key industrial cities of China, raising the construction and operation costs of the pipeline (Lague 2002).

The Japan factor further complicated the viability of the pipeline. In November 2002 the Russian Federal Security Commission, chaired by Vladimir Putin, discussed the routeing of the pipeline from Angarsk. The Commission reportedly favoured a port in the Far East as the destination (Huanqiu shibao, December 19, 2002: 16). With an aim to reduce its heavy dependence on oil from the Gulf region, Japan's Prime Minister Junichiro Koizumi in his visit to Russia in January 2003 lobbied for a rival pipeline to the Pacific port of Nakhodka, near Vladivostok (the Pacific line, for short). Japan showed willingness to provide low-interest loans for the project that would cost US $\$ 5$ billion. Japan was allegedly ready to purchase all the oil 
that would be shipped through the pipeline to the Pacific port and was willing to participate in the construction. The Japanese scheme was supported by Transneft, a Russian state-owned pipeline operator, and believed to be preferred by Moscow. With an annual throughout capacity of 50 million tonnes, the Pacific-bound pipeline would serve Russian interests by facilitating Russian exports of oil to multiple markets, including Japan, South Korea and even the US, and, more importantly, by allowing it to retain control over the exports of oil, as the pipeline is built on Russian land. Russia also held that it would be inadvisable to rely solely on a pipeline running into an 'enclosed market, that is, China' (Gorst 2003b).

In the wake of the growing competition between Asia's two largest oil consumers, the Russian government delayed making a decision on the routeing of the pipeline. In the meantime, its Energy Ministry reportedly favoured a compromise plan which was to build a 1,700-km pipeline linking Angarsk to Chita, a town about $50 \mathrm{~km}$ from the Chinese border. From there, the pipeline would be divided into two, with one going to Nakhodka and another running south to Daqing. In making the proposal, Moscow stressed that the pipeline stretching towards Nakhodka would be the key pipeline of the plan, with the one going to Daqing being a separate branch (SCMP 2003a, 2003b; Ta Kung Pao [Hong Kong], March 16, 2003: A7).

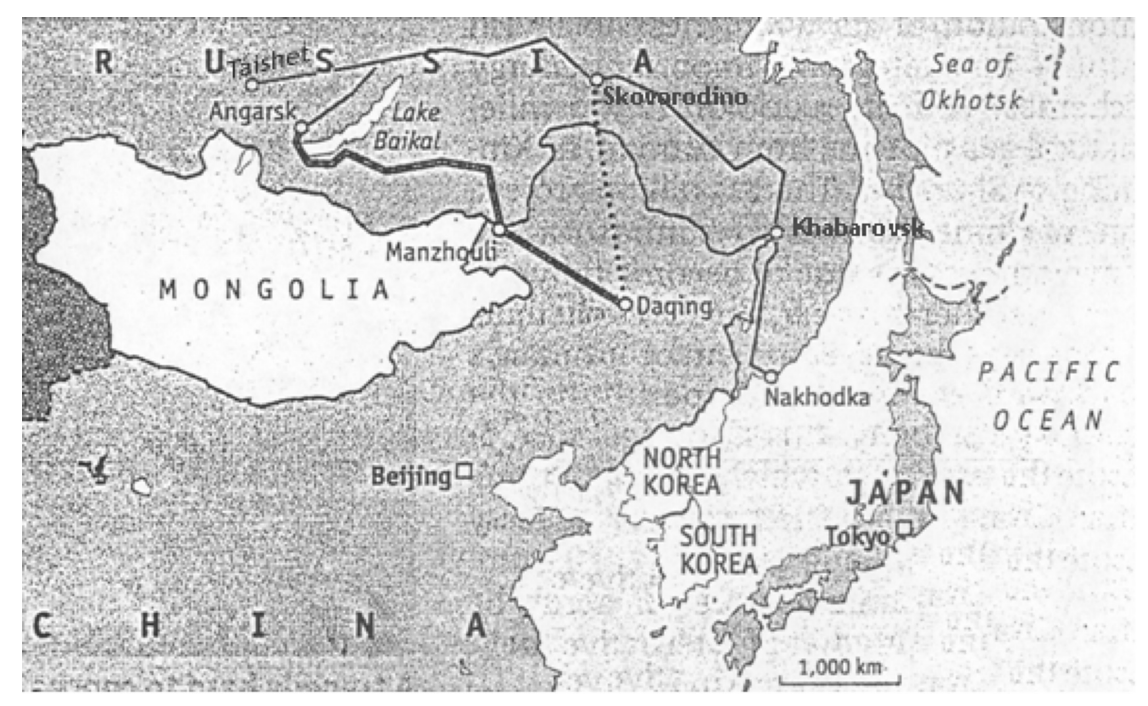

Map 2 Russian far eastern oil pipelines

Source: Adapted from Economist Newspaper (2004b).

However, the remaining issue was whether oil reserves in eastern Siberia would be sufficient enough to serve the needs of China and Japan. According 
to Transneft, the pipeline would need to deliver at least 50 million tonnes (365 million barrels) of oil per annum over twenty years to make it economically viable. For Yukos, which supports the route to China, the proven oil reserves in its fields in eastern Siberia are sufficient for supplying oil to China or Japan, but not both, for two decades, whereas the Russian Energy Ministry boosted that the pipeline would eventually pump 80 million tonnes (584 million barrels) of oil annually by 2020 (Bellaby 2003; Jack and Pilling 2003; Jack et al. 2003; Lim 2003; Peel and Jack 2003). China was reportedly willing to accept the compromise plan as long as Russia could guarantee adequate supplies -20 million tonnes of crude oil annually from 2005 and 30 million tonnes by 2010 - for China (L. Wang 2003). For Japan, the least preferable option was China monopolizing control over Siberian oil (Jack and Rahman 2003). Citing that the Angarsk oil reserve was not large enough to sell oil to both China and Japan, then-Russian deputy foreign minister Alexander Losyukov said in mid-April 2003 that Russia had rejected a Japanese proposal to construct a trans-Siberian pipeline to provide Japan with oil, and would instead build a shorter pipeline to Daqing. Russia, however, had modified the Chinese proposal by routeing the pipeline north of Lake Baikal. The new route would overlap to a certain extent the one favoured by Japan. It left open the possibility of building a branch pipeline to Nakhodka in the future (Kyodo 2003a, 2003b; SCMP 2003c).

However, under strong lobbying from Japan, which sent delegations of energy officials and diplomats to Moscow in April 2003 with an offer to finance the entire Japan-bound pipeline project, Russia changed tack in one month's time. ${ }^{16}$ In May 2003 Koizumi asked Putin to overturn the Russian Duma's earlier decision to send the oil to China. In response, Putin assured Japan that he supported the Pacific route (Gorst 2003c; Lim and Gismatullin 2003). ${ }^{17}$ It was initially expected that when Chinese President Hu Jintao visited Russia in late May 2003, the two countries would seal the deal (Hutzler 2003; Wen Wei Po, May 27, 2003: A5). But what China could achieve in the summit meeting was only that China National Petroleum Corporation and Yukos signed a 25 -year oil deal worth US $\$ 150$ billion. CNPC would buy up to 5.13 billion barrels of oil between 2005 and 2030, representing 10 per cent of China's oil needs in the period. The deal would also help China revitalize the industrial economy of its northeastern provinces. But Vladmir Putin was non-committal to the Daqing pipeline by saying that the routes needed to be further discussed by experts. The oil deal was only said to 'pave the way' for the pipeline (21 shijie jingji baodao, June 2, 2003, 2; Hu 2003; Raff 2003; SCMP 2003d; Wen Wei Po, May 29, 2003: A3). Putin said, however, in June that the Pacific pipeline 'looks preferable because it allows broad access to markets' (Oil and Gas Journal, July 7, 2003: 9).

To regain the initiative from China, Japan dispatched a delegation, led by Iwao Okamoto, director-general of the Natural Resources and Energy Agency, to Moscow in July 2003. The Japanese energy officials discussed with their Russian counterparts about providing financial and technical assistance 
to the construction of the Pacific pipeline and the development of oilfields in eastern Siberia. The Japan Bank for International Cooperation was said to be willing to finance the construction project even without any loan guarantees from the Russian government. ${ }^{18}$ The state-owned Japan National Oil Corporation would also offer technical assistance to Russia to help develop Siberian oilfields. As a result, when then-Russian Prime Minister Mikhail Kasyanov visited Beijing in September, he openly declared that the Daqing pipeline had been postponed for several months. Prior to the visit by Kasyanov, Russia postponed meeting with Chinese officials on the pipeline and the Russian Ministry of Natural Resources, an ecological commission, rejected the two routes for environmental reasons (Liaowang, September 15, 2003: 58-60; Wiest 2003; Zhdannikov 2003). The promise Kasyanov made to China that his country would uphold its commitments to supply oil to China carried little weight.

The fate of the Daqing line was also clouded by the arrest of Mikhail Khodorkovsky, chief of Yukos, in October 2003. Yukos under Khodorkovsky had supported the building of the Daqing pipeline that would carry crude oil from its fields in the Tomsk region of western Siberia and would reduce its dependence on the state-owned oil transport company. In contrast, both the state-owned pipeline operator Transneft and oil producer Rosneft favoured the Pacific route.

The substance of the Japanese financial offer became more concrete in October 2003 when a Japanese delegation, which included Deputy Foreign Minister Hitoshi Tanaka, visited Moscow. Japan revealed that it would provide US $\$ 5$ billion in low-interest loans to support the construction of the Pacific pipeline and a further US $\$ 2$ billion for the discovery and development of eastern Siberian oilfields. Despite the Japanese hope that an agreement would be reached when Kasyanov visited Tokyo in December 2003, Kasyanov did not clearly indicate which pipeline Russia was likely to approve. Kasyanov even suggested that even if the Pacific oil pipeline were to be built it would not happen for at least five to seven years (Gismatullin and Lim 2003; Okada and Dobashi 2003; Platts 2003d; Rahman and Jack 2003). The rivalry between China and Japan and the stand-off between the Kremlin and Khodorkovsky led to an unlimited delay to reach a final decision on the routeing of the pipeline. Meanwhile, as mentioned above, Russian officials were studying a compromise project that would construct a main pipeline to Nakhodka with a spur to Daqing. China was apparently not opposed to this compromise solution, but insisted that the Daqing line be built first (Bezlova 2003; Hsieh 2003; Platts 2003b; Zhdannikov 2003). Igor Yusufov, then Russian energy minister, hinted in February 2004 that Russia was leaning towards the construction of the Pacific line due to its greater strategic importance to the country. The pipeline was to be built by the state-owned Transneft (AFP 2004a; Gismatullin 2004). Russia and Japan had reportedly agreed in March 2004 to build an oil pipeline from Taishet, about $500 \mathrm{~km}$ northwest of Angarsk, in eastern Siberia to Nakhodka. The pipeline would 
have a branch going to Daqing. A Japanese government official added that it was uncertain which line - the main pipeline or the spur line - would be constructed first. China found the branch line, supplemented by increased oil delivery by railway, acceptable (SCMP 2004a; Xie 2004). Viktor Khristenko, Russian Minister of Industry and Energy, told Liu Guchang, China's ambassador to Russia, in late June 2004 in Moscow that Russia had already abandoned the Angarsk-Daqing and Angarsk-Nakhodka lines. Instead, according to Khristenko, the Taishet-Nakhodka route would be the most reasonable one. As soon as the routeing of the pipeline could be finalized, Russia would start discussing with China about branching off the pipeline to China (Huanqiu shibao, July 2, 2004: 2; 21 shiji jingji baodao, July 5, 2004: 9).

While Chinese Premier Wen Jiabao was in Moscow in September 2004 to push for the Kremlin to give priority to 'the construction of a pipeline in the direction of China' by pledging to invest US $\$ 12$ billion in Russian infrastructure and energy sector, Alexander Losyukov, Russian ambassador to Japan, revealed in Tokyo that his country had already decided to build a pipeline to Nakhodka and that the decision would be announced in a couple of months. What Wen received from the Russian government was once again a vague commitment that the latter would 'actively consider' the option of the Daqing branch after the approval of the feasibility study of the Pacific route (AFP 2004d; Blagov 2004b; Prime-TASS 2004a; SCMP 2004d; Shi 2004b; Wen Wei Po, September 21, 2004: A8; September 26, 2004: A4). During Putin's visit to Beijing one month later, the two countries still failed to agree to the pipeline, despite signing a raft of agreements, including one on the demarcation of the border along the Ussuri river, a dispute that had lingered for forty years. China had intended to concede on the border issue in return for a 'reciprocal-friendly gesture' on the part of Russia. However, with an emphasis on the eve of the visit that his country's national interests would come first in deciding where to build the pipeline, Putin hinted that the final decision would not favour China (BBC News 2004b; SCMP 2004g). ${ }^{19}$ On December 31, 2004, the Kremlin announced that Transneft would construct a 'system of pipelines' with an annual capacity of 80 million tonnes (1.6 million barrels per day) from Taishet to Perevoznaya near Vladivostok and Nakhodka. In the Russian statement there was no mention of a spur going to China (AFP 2004g; SCMP 2005a) ${ }^{20}$ Frustration not with standing, Beijing has not stopped lobbying Moscow for a branch line from Skovorodins (Economist Newspaper 2005; Kyodo 2005; SCMP 2005f).

Besides the intervention of Japan, another factor leading to the change of Russian attitude towards the Daqing pipeline is the scepticism on the part of the Russian leadership, particularly the Russian Far East leaders, about China's robust economic growth and growing influence in Northeast Asia (Zhu 2003). Rosneft was particularly concerned that if China became a monopoly buyer of Russian oil, China would initiate renegotiation over import price or volume before the completion of the pipeline. As noted before, Igor Yusufov, then-Russian energy minister, said in March 2003 that 
'it would be inadvisable to rely solely on a pipeline running into an "enclosed market, that is, China"'(Gorst 2003a, 2003d).

Earlier, in late 2002, China suffered another setback in its attempt to purchase a 74.95 per cent stake in the state-owned Slavneft, eighth-largest oil company, at a privatization auction in Russia. Slavneft produces 14 million tonnes of oil per year (or 280,000 barrels per day) from fields in western Siberia, and holds prospective licence areas in the Krasnoyarsk region in eastern Siberia. But the participation by China National Petroleum Corporation encountered stiff resistance from the Russian Duma, which voted days before the auction in favour of a resolution against foreign investors' purchase of the state-owned oil company (Platts 2002a, 2002b). Members of the Parliament had been concerned that Russian strategic resources would fall under Chinese control. CNPC dropped out of the auction at the last minute. Slavneft was bought by Sibneft and Tyumen Oil (TNK), two Russian oil companies, at a price of US $\$ 1.86$ billion, far short of the US $\$ 3$ billion CNPC was reportedly willing to pay (FEER 2003; IHT 2002).

To summarize, Chinese oil diplomacy with its neighbours to the north is far from successful. This failure on the part of China would likely have broad and far-reaching ramifications for regional security and for China's relationships with global and regional powers, as discussed below.

\section{Implications for regional security}

China's surging demand for oil as a result of its continuous economic growth and declining domestic oil output has given rise to an energy insecurity that began to seize the attention of its leaders in the early 1990s. One has to note, however, that China's current oil security strategy reflects not only Beijing's desire to satisfy its booming demands for oil imports, but also its endeavour to minimize its economic vulnerability to US power. This paper discussed in detail in preceding sections the strategy, focusing on how it tries to diversify its oil supplies from the Middle East to Central Asia and Russia.

The futile attempts in the former Soviet Union have posed challenges for regional security. First, it strains China's relations with Russia. Second, China and the US - the two largest oil consumers - will likely be increasingly competing for oil resources in the Middle East and elsewhere. With both countries' dependence on imported oil growing, competition over energy resources between the US and China looms large. ${ }^{21}$ Furthermore, in view of the failure to secure oil resources in Russia and Central Asia, China will push ahead with developing offshore energy resources in East and South China Seas, heightening the danger of deteriorating territorial disputes between China and its neighbours, particularly Japan and the Southeast Asian nations. It is also likely that China and India - two oil-poor, rivalling and populous countries in Asia - will intensify their scramble for oil resources in oil-producing countries. 


\section{Strained relations with Russia}

Aspiring to be a major, independent oil exporting country, Russia under Vladimir Putin is tightening its grip on the country's oil industry by granting state-owned companies monopoly rights in pipeline operations. ${ }^{22}$ The pipeline going to Nakhodka instead of Daqing would allow Russia to undertake oil diplomacy not only with such East Asian countries as China, Japan and South Korea but also possibly with the United States. Feeling the need to reduce over-reliance on Middle Eastern oil, the West, particularly the US, has looked to Russia - the world's second-largest oil exporter, behind Saudi Arabia - as a new source of crude oil. Western oil conglomerates such as BP, ConocoPhillips and TotalFinaElf have made inroads into the country's oil sector (Arvedlund and Mouawad 2004; OGJ 2004). ${ }^{23}$ Also, Russia anticipates that untapped oil resources in its Far East could be developed as a result of the Pacific route, boosting the economies of the less developed region. In addition, according to Igor Rogachev, Russia's ambassador to China, Russia does not want its exports to China to be limited to raw materials and primary products. Rather, it is at pains to promote its energy equipment and technology to the Chinese market (Huanqiu shibao, September 22, 2004: $20)$. With regard to national interests, there are obvious grounds for Russia not to opt for the Daqing route.

In contrast, China is concerned about the steady inflow of oil from the north. With worries about the possible forced sell-off of Yukos, China in August 2004 sought reassurances from Moscow that oil deliveries would not be adversely affected (Chazan and Robbins 2004). ${ }^{24}$ China has also resented the abolition of the pipeline option after a lengthy process of negotiations. It would undermine China's trust in the credibility of the Russian government and the basis of the 'elite-initiated and elite-managed' strategic partnership between the two powers (quoted in Dittmer 2004: 336; see also Huanqiu shibao, October 20, 2003: 3; Feng and Xiang 2004: 205). In the wake of the demise of the Daqing project, it was reported that China raised the thresholds for Russia to join the World Trade Organization, requiring Russia to raise the domestic prices of natural gas to international levels (Ta Kung Pao, July 30, 2004: A4;21 shijijingji baodao, September 23, 2004: 6). ${ }^{25}$ With the disparity in the relative national power of China and Russia widening, there is likelihood that Russia seeks to offset Chinese growing influence by aligning itself with Japan, which, like Russia, is a declining power in Northeast Asia. ${ }^{26}$ Except in arms transfers, the bilateral relations and common interests between China and Russia seem to be more in word than in deed.

To compensate for China's 'loss', Russia agreed that it would lift its annual oil exports by rail to China from 6.5 million tonnes in 2004 to 10 million tonnes in 2005 and to strive for a shipment of 15 million tonnes in $2006 .{ }^{27}$ The state-owned Russian Railways said in September 2004 that it would spend more than US $\$ 1$ billion to upgrade and expand its rail link to China in order to double two-way cargo deliveries to 60 million tonnes by $2010 .{ }^{28}$ Despite 
these, it was unclear as to which companies would provide China with the oil, for the Russian government warned that it would not give China any guarantee of Yukos shipments. Due to high transportation cost and export duties, other Russian oil suppliers, including Lukoil and Surgutneftegaz, failed to reach an agreement with Transneft to sell oil to China's CNPC (21 shiji jingji baodao, September 23, 2004: 1, 2; Blagov 2004a, 2004b, 2005; Kyodo 2004; SCMP 2004c, 2004e; Ta Kung Pao, September 23, 2004: A2; WPS Russian Media Monitoring Agency 2004b). After the auction for Yuganskneftegaz, the main subsidiary of Yukos (see above), Russia's Minister of Industry and Energy, Viktor Khristenko, stated that China National Petroleum Corporation could be offered up to 20 per cent of a newly created state-owned company to which the asset of Yuganskneftegaz would be transferred. It seems that CNPC is quite cautious about purchasing the stake. It is because Yukos's main shareholder in the US has threatened to file suit against the owner of Yuganskneftegaz. Days prior to the auction, Yukos sought protection from its creditors under Chapter 11 of the US Bankruptcy Code in a US bankruptcy court in Houston, Texas. The court issued on December 16, 2004, a temporary injunction to block Gazprom from taking part in the auction. Moreover, the offer was not attractive to the Chinese. According to Li Fuchuan, a researcher at the Institute of Russia, East Europe and Central Asia of the Chinese Academy of Social Science, without holding at least a 25 per cent stake in Yuganskneftegaz, CNPC would have little say about where the Russian oil would be sold (21 shiji jingji baodao, January 6, 2005: 10; Blagov 2004c, 2005; Myers 2004; Ostrovsky 2005; White and Pottinger 2005).

\section{Potential conflicts with the US in the Middle East}

Aware that the attempts to exploit oil resources in Russia and Central Asia would be slow to materialize, China has no alternative but to continue, at least in the short run, to rely on the energy resources in the Middle East to sustain its industrialization drive. China is therefore strengthening its ties with Saudi Arabia, Iran and other countries in the region..$^{29}$ For instance, China began considering developing Iran's largest Azadegan oilfield, which is estimated to contain 3.55 billion tonnes of oil (26 billion barrels), after Japan bowed to US pressure to suspend negotiations on developing it. In late 2000, a Japanese consortium of Tomen, Inpex and Japan Petroleum Exploration (Japex) was granted by the Iranian government priority rights to negotiate a US $\$ 2.8$ billion deal to develop the southern half of the oilfield. But the US government voiced opposition to the deal, citing concerns over Iran's nuclear weapons programme. Since then, Iran has entered into negotiations with international corporations. The country's Oil Minister, Bijan Zanganeh, said in September 2003 that Japan had lost its exclusive rights to developing the oilfield (Bozorgmehr et al. 2003; Lewis 2003; Nihon Keizai Shimbun 2003; Platts 2003a). The Iranian Deputy Oil Minister for International Affairs, 
Hadi Nezhad Hoseyniyan, was quoted in December 2003 as saying that Chinese corporations expressed readiness to participate in the tender for the development of the Azadegan project (BBC 2003). To allay American worries, Tokyo urged Tehran to sign an agreement with the International Atomic Energy Agency (IAEA) that would allow the international organization to monitor Iran's nuclear facilities. In mid-December 2003, Iran signed an additional protocol to the Nuclear Non-Proliferation Treaty, enabling the United Nations watchdog to carry out unfettered inspections of the nuclear facilities that Iran has insisted are for non-military purposes. Bilateral Iranian-Japanese talks continued in January 2004 when Japanese Foreign Minister Yoriko Kawaguchi visited Iran (Eqbali 2003, 2004). Japan finally clinched the deal with Iran in February 2004, whereby the Japanese consortium would invest more than 200 billion yen (about US $\$ 1.9$ billion) and import 300,000 to 400,000 barrels per day from the oilfield (BBC News 2004a; Sanchanta 2004; Yomiuri 2004). Japan still finds itself contending with China, which is bidding for the rights to develop the northern half of the field (Richardson 2004a). It was reported in April 2004 shortly after the visit by Iranian Vice-President Mohammad Sattarifar to China that China Petroleum and Chemical Corporation (Sinopec) was in talks with Iran to import annually at least 5 million tonnes of liquefied natural gas from it. In return, the Chinese company would be granted the rights to exploit the Azadegan oilfield (Liu and Xie 2004). In addition, in defiance of US pressure, Sinopec was determined in early 2004 to make a bid for oil exploration and development contracts in Iran, which reportedly offered more attractive terms of cooperation to interested overseas investors. In October 2004 China and Iran signed a preliminary accord whereby Sinopec was to buy 250 million tonnes of Iranian liquefied natural gas over thirty years and to develop Iran's Yadavaran oilfield in the southwest, close to the Iraqi border, which would sell 150,000 barrels per day to China, over twenty-five years. The deal as a whole is estimated to be worth US\$70-100 billion. Iran also expressed its preference that China would replace Japan as its biggest oil and gas buyer (Richardson 2004d; Wright 2004). Earlier in 2001, Sinopec had struck a deal to explore oil in central Iran's Zavareh-Kashan and has discovered crude oil there (Mai 2004; 21 shijie jingji baodao, February 2, 2004: 9).

China has forged increasingly close relations with Saudi Arabia in the energy sector since Jiang Zemin's visit to the kingdom in 1999 (Andrews-Speed et al. 2002: 65-7). In 2004 alone, Sinopec was awarded a concession in January to explore and produce natural gas in Saudi Arabia. Surprisingly, leading oil companies from the US and Britain were absent from the three concessions the Middle East kingdom offered to international firms, prompting speculations that Saudi Arabia was distancing itself from the United States in the wake of the Iraq war (Economist Intelligence Unit 2004a). In early July China and the Gulf Cooperation Council, which comprises Bahrain, Kuwait, Oman, Qatar, Saudi Arabia and the United Arab Emirates, announced that 
they would start talks to establish a free trade agreement. It was widely believed that the free trade agreement would help China shore up its energy supplies (AFP 2004b; 21 shiji jingji baodao, July 8, 2004: 26; July 15, 2004: 3; Huanqiu shibao, July 9, 2004: 7). Even non-petroleum business agreements between China and the Gulf states were made with a view to securing China's oil needs (Daragahi 2005).

China's closer relationships with oil-producing nations in the Gulf region, particularly those non-US-friendly, have raised American eyebrows. The US is concerned that an emerging strategic alliance between China and Iran that largely grows out of the former's rapidly increasing energy demands could undermine US ability to put international pressure on Iran over its nuclear programme. China has voiced its opposition to an American move to refer Iran to the Security Council of the United Nations over its nuclear programme (Ma 2004; Richardson 2004d; Wright 2004). In addition, the US-China Economic and Security Review Commission (2004: 152) has harboured suspicion that China's outreach to certain oil-rich 'states of concerns' such as Iran (and Sudan in Africa) might involve a transfer of weapons and military technologies in return for oil from the countries. As a matter of fact, half of China's net arms sales to the Middle East between 1995 and 2002 went to Iran. In the same period, China was Iran's second largest military supplier, providing the Persian state with 28.6 per cent - in terms of value of what it had acquired (Klare 2004: 173-4). ${ }^{30}$

\section{Scramble for hydrocarbon riches among Asian nations}

The competition over oil between China and Japan unfortunately renews tensions and distrust between the two Asian powers. On the one hand, Japan feels threatened by China's ballooning growth of oil and gas imports, which would make it less able to find sufficient energy resources in the international market. In August 2004 Japan struck a cooperation agreement with four Central Asian nations - Kazakhstan, Kyrgyzstan, Uzbekistan and Tajikistan. Japan would provide economic aid to the Central Asia states in return for cooperation in a number of areas including energy (AKIpress 2004; Blagov 2004a; 21 shiji jingji baodao, September 6, 2004: 33). The Japanese move was viewed as a strong sign that Japan has spared no effort to promote its economic and political presence in oil-producing areas. ${ }^{31}$ On the other hand, China is so paranoiac that it views the Japanese intrusion into the Sino-Russian oil deal as a means whereby Japan aims not only to strengthen its political clout in East Asia but also to contain China. Lu Nanquan, a vice director of the Russian Research Centre at the Chinese Academy of Social Sciences in Beijing, holds that Japan's move aims at weakening China's stable economic growth by threatening its energy security and at adversely affecting the strategic partnership between China and Russia (Shijie zhishi, October 16, 2003: 44-6; Huanqiu shibao, August 11, 2004: 7). The Japanese involvement in the construction of the pipeline intensifies the 
security dilemma facing China and Japan. ${ }^{32}$ In response, China has actively competed with Japan over oil in Iran as well as in China's offshore areas between the two nations.

The setbacks in Central Asia and Russia inevitably prompt China to pay increasing attention to the energy resources in the country's offshore areas. Apart from the mutual competition over the routeing of the Russian oil pipeline discussed above, conflicts between China and Japan over the exploitation of oilfields in the East China Sea have recently become intense. They hold competing views of how the boundary of its respective exclusive economic zone (EEZ) is to be drawn, though both allege that they abide by the rules laid down in the United Nations Convention on the Law of the Sea. China claims that its EEZ should extend to the edge of the continental shelf (i.e. close to Okinawa). Defining the boundary as a line equidistant from the coasts of the two countries, Japan expressed concerns about the construction of new Chinese natural-gas drilling rigs close to its EEZ in the East China Sea - just $4 \mathrm{~km}$ away from the median line between the two countries' coasts. Japan contended that China could siphon off resources from Japan's EEZ, even though legally speaking the rigs are in Chinese territory. ${ }^{33}$ It has been estimated that the East China Sea holds 6-7 billion tonnes of oil and gas, much of which lies in the west of the centre line (Huanqiu shibao, June 28, 2004: 7; Shijie zhishi, July 1, 2004: 34-5; Takahashi 2004).

In June 2004, Shoichi Nakagawa, Japan's Minister of Economy, Trade and Industry, met Zhang Guobao, vice minister of China's State Development and Reform Commission, on the sideline of a meeting of energy ministers from the Association of Southeast Asian Nations (ASEAN) plus Japan, China and South Korea in Manila. At the meeting Nakagawa expressed Japan's concern and asked China to present solid evidence that the gasfields do not encroach on Japan's EEZ, but the Chinese side was reportedly non-committal (Muramatsu 2004; Nihon Keizai Shimbun 2004). Later in the same month, Yoriko Kawaguchi, Japan's then foreign minister, reiterated the country's worry over the Chinese move in a meeting with her Chinese counterpart, Li Zhaoxing. Kawaguchi urged China to provide more information about the project. China countered by arguing that Japan had no right to request the information, as China was exploring only its own areas of the East China Sea (Far Eastern Economic Review, September 16, 2004: 32; Xinhua 2004).

In mid-June a Liberal Democratic Party working team on the rights to the surrounding waters submitted a proposal on protecting maritime interests to the Chief Cabinet Secretary Hiroyuki Hosoda. The proposal called for an appointment of a Cabinet minister with responsibility for policy in protecting maritime interests and for test-drilling natural resources in Japanese territorial waters in the East China Sea. In July, Japan sent survey ships to conduct research in its own EEZ (Okubo 2004). Japan currently possesses no ships equipped with specialized devices that send seismic waves to the seabed. Coinciding with the release of a revamped National Defence Programme 
Outline, covering the period April 2005 to March 2009, which singled out China and North Korea as potential threats to the country (Brooke 2004; Huanqiu shibao, December 13, 2004: 16), Japan was reported to start building a high-performance ocean survey vessel, estimated to cost 20-24 billion yen, to gauge the size of the underwater reserves in the Sea. Since July 2004 Japan has charted a Norwegian ship for the research. In January 2005 two Japanese oil firms sought permission from their government to drill for oil and gas in a disputed area in the East China Sea. Tokyo was expected to grant approval and subsidies to the two companies (AFP 2004f; Nihon Keizai Shimbun 2004, 2005; SCMP 2005c). The United States had urged the two countries to exercise restraint over the issue. Although the US claims that it is non-partisan in the maritime dispute, it is rather generally believed by China that it is part of Japan's national strategy to side with the US to contain China (Zhang 2004).

Another flashpoint in China's offshore areas is the South China Sea. In spite of the fact that China and ASEAN signed in November 2002 a joint declaration on the code of conduct regarding territorial disputes in the South China Sea, the Chinese Academy of Sciences has established a research centre in Guangzhou for exploring and developing natural gas hydrates in the South China Sea and sent a research team to the Sea in June 2004 (Wiest 2004a). Apparently with an aim to demonstrate its presence and authority in the area, Vietnam, a claimant to the disputed Spratly Islands, sent a group of tourists to the islands in April 2004 and announced four months later that it would start commercial flights to an island in the atolls (FEER 2004a; Richardson 2004b). Departing from a long-standing unwritten convention in China's oil industry that CNPC concentrates on onshore oil exploration and production while $\mathrm{CNOOC}$ is dominant in offshore activities, Beijing has allowed CNPC to step into the South China Sea. This bears testimony to China's determination to speed up exploring oil and gas resources in the area (IHT 2004a; Xiao 2004).

In September 2004 two Chinese and Filipino state oil companies reached a deal on research on parts of the Spratly Islands when the Philippine President Gloria Macapagal-Arroyo visited China. The two countries began to hold discussions about joint exploration in the islands in 2003 after CNOOC sealed an agreement with the exploration arm of the Philippine National Oil Company (PNOC) in November 2003 to study the possibility of joint exploration and production in the South China Sea and in the Philippines. The talks between the two state-owned oil enterprises followed a visit by Wu Bangguo, chairman of China's National People's Congress, to the Philippines in August-September 2003 (Mai 2003b; Reuters 2003a, 2003b). Although both countries wished to play down the significance of the three-year agreement to do joint marine seismic work signed by PNOC and CNOOC, it has been believed that the deal would arouse the ire of rival claimants to the disputed territories in the South China Sea. Vietnam complained that the two countries had violated the agreement on the code of conduct on the South China 
Sea (AFP 2004c) ${ }^{34}$ More importantly, the deal opened the way for China to promote bilateral discussions about energy exploration as well as accommodation of the territorial conflict (Boyd 2004; Dickie and Landingin 2004; Tan 2004). It remains to be seen whether the agreement would rekindle tensions in the region, particularly when and if the two companies find potential oil and gas reserves in the area. One month later, however, the Vietnamese government came under strong criticism from China for its 'unilateral' oil exploration near the disputed Spratly Islands (Reuters 2004a).

Another area of concern in Southeast Asia is the Strait of Malacca through which about 80 per cent of China's imported oil passes. Chinese energy analysts have proposed various measures to reduce dependence on shipping oil through the Strait for fear that the Strait would come under American control. Earlier in March 2004 Admiral Thomas Fargo, commander of US Pacific Command, proposed a Regional Maritime Security Initiative whereby the US would cooperate with regional countries to combat terrorism and piracy around the Strait. Initially the US proposed to station its elite forces to patrol the Strait, together with Singapore, Malaysia and Indonesia. Only with the opposition of Indonesia and Malaysia, could the four countries agree that the vital waterway would be jointly patrolled by the three littoral states (Burton and Donnan 2004a, 2004b; IHT 2004b). The Strait has evolved into the latest issue at the forefront of the rivalry between China and Japan. Singapore's Defence Minister Teo Chee Hean said in December 2004 that the joint patrols of the Strait would be more effective if other like-minded countries, including Japan, could participate. In a prompt response, Japan indicated that it was willing to offer assistance to boost the security of the Strait (Dow Jones 2004; Huanqiu shibao, December 13, 2004: 2; Jakarta Post 2004). Some Chinese analysts argue that the US would use strengthening maritime security as a pretext to exercise dominance in the vital shipping lane and consequently threaten China's oil security. Accordingly, a number of alternative oil transportation routes, which would enable oil delivery bypassing the Strait, have been proposed. One of them is to build a canal through the Kra Isthmus in southern Thailand, through which oil tankers would go from the Andaman Sea to the Gulf of Thailand. Another alternative is to develop the port of Gwadar in southwestern Pakistan, followed by a pipeline to Xinjiang over the Karakoram Pass. The third option, proposed by China's Yunnan provincial government, is to build an oil pipeline from Myanmar's western deepwater port of Sittwe in the Bay of Bengal to the city of Kunming in Yunnan. It seems that China is less interested in the Thai waterway than in the Burmese project simply for the reason that Thailand is an ally of the US, which has military bases in the country. However, for the Burmese pipeline to be operational, China has to invest massively in the infrastructure of refineries in Kunming as well as a network of pipelines taking the oil products to coastal consumers. The viability of the Pakistani route is also in doubt because it has to pass through the politically volatile Kashmir area on the border of Pakistan and India with China (21 shiji jingji baodao, 
December 30, 2004: 30; Jingji cankao bao [Beijing], August 2, 2004: 2; Shijie zhishi, July 1, 2004: 46-51; December 16, 2004: 25; Wen Wei Po, January 10, 2005: A20; Becker 2004; Lam 2004; Richardson 2004c; Tschang 2004).

China's voracious appetites for oil and its worldwide quest for oil security have also fuelled the concerns of India, another Asian fast-growing economy, about its own energy security. In recent years Indian domestic annual oil production has been stagnant at more or less 36 million tonnes while its annual oil consumption had risen steadily to 113 million tonnes in 2003 from 63 million tonnes in 1993 (British Petroleum 2004: 7, 10). The South Asian country relies on overseas supplies for 70 per cent of its crude-oil demand. Akin to the strategy used by China, India has strengthened its presence in oil-rich countries to secure its oil supplies. In January 2005, India's Oil and National Gas Corporation (ONGC) was reportedly in talks with Russia about investing in Yukos shortly after the auction for Yuganskneftegaz. ONGC could spend as much as US $\$ 2$ billion for a 15 per cent stake. Subir Raha, the Corporation's chairman and managing director, has said that India and China would be engaging in fierce competition over energy sources. Mani Shanker Aiyar, India's Minister of Petroleum and National Gas, was touring Kazakhstan and Russia in February 2005. In Moscow he met Rosneft's head, Sergei Bogdanchikov, as well as his Russian counterpart, Viktor Khristenko, and reportedly expressed interest in acquiring stakes in Yuganskneftegaz. In the same month, a subsidiary of ONGC also clinched a 25-year deal with National Iranian Oil Company to import liquefied natural gas and develop two Iranian oilfields, including Yadavaran, in which China has also invested, and a gasfield. India shows an interest in importing gas from Myanmar through Bangladesh. While it battles with China for oil resources in West Africa, notably in Angola, India is exploring the possibilities of investing in the oil industry in Ecuador in South America and in Saudi Arabia. As a sign of his worries about China's relative gains, Indian prime minister, Manmohan Singh, said in January 2005 that his government would restructure stateowned oil firms to enable them to compete with China over oil (AFP 2004e; Bhadrakumar 2005; Bradsher 2005; Browne et al. 2005; Buckley et al. 2005; Ghosh 2005; IHT 2005; Luce and Morrison 2005; SCMP 2005e; White et al. 2005). ${ }^{35}$

China's search for oil security has opened up a new contentious issue in the country's foreign policy. A couple of great and middle powers are involved in China's bid to enhance its energy security. The oil diplomacy also has much bearing on one of the guiding principles of China's foreign relations in the twenty-first century decided by the Chinese Communist Party in its 16th National Congress in November 2002, namely cementing friendly ties with neighbouring countries and building good-neighbourly relations and partnership with them (Jiang 2002). Recently, in meetings of regional international institutions, China has called for strengthening regional energy cooperation. ${ }^{36}$ In the years to come, one might need to closely monitor and examine whether China, in seeking to satisfy its surging demand for energy 


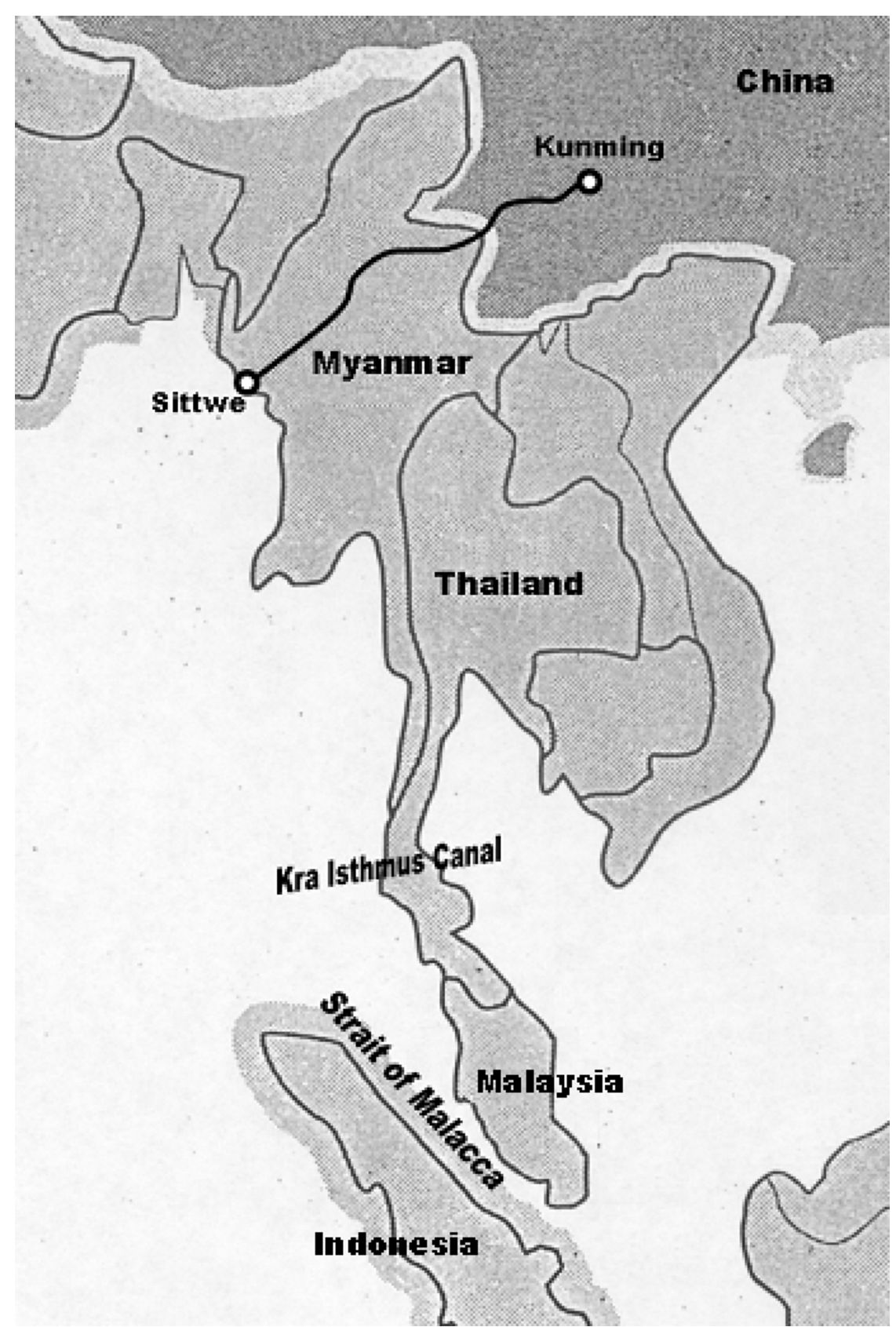

Map 3 The Strait of Malacca and alternative routes

Source: Adapted from 21 shiji jingji baodao, November 15, 2004, p. 1 
resources, could cooperate and resolve conflicts with the major powers of Russia, Japan and India, as well as the United States, and with the middle powers in the south, or unfortunately exacerbate actual or potential tensions with them.

\section{Conclusion}

The once oil self-reliant China began to feel insecure immediately after 1993 when it had to rely on foreign petroleum to meet its rising oil demand. Given the difficulty in reversing its growing dependence on imported oil, China is at pains to safeguard its oil security by seeking out other oil suppliers. However, the results so far have at best been mixed.

More notable about its oil security strategy is rather that with security being seen as reducing vulnerability to being subject to the power of others, China tends to view its oil security through the prism of American-Japanese containment of China. Overall, China's quest for oil security has far-reaching geostrategic repercussions for the security of the Asia-Pacific region. Worries about the US quest for hegemony - with Japan playing the role of a junior partner - and the distrust of Russia on the part of China do not augur well for security and stability in the region. It is likely that oil wars, instead of oil, are in the pipeline. Possibilities of bilateral or multilateral energy cooperation are, in contrast, rather remote.

In addition, this paper has demonstrated the significance of studying China's oil security and diplomacy. It broadens the scope of the study of China's security by joining non-traditional security (economic security) and traditional security (territorial integrity). China's foreign relations with its adjacent countries of Russia, Japan, Southeast Asia and India, as well as with the global power of the United States, are also involved in China's oil diplomacy.

\section{Acknowledgements}

I am grateful to two anonymous referees as well as Gerald Chan for their thoughtful comments and suggestions. Earlier drafts of this paper were presented to the 14th and 15th Biennial Conferences of Asian Studies Association of Australia in July 2002 and June-July 2004 respectively, and to the First Congress of the Asian Political \& International Studies Association in Singapore in November 2003. I would like to thank the participants, especially Gaye Christoffersen and Ann Kent, for their questions and helpful comments. Special thanks go to Lai Ha Chan and Spandy Lai for their respective excellent research and technical assistance.

\section{Notes}

1 See also IEA's Oil Market Report dated January 16, 2004, available at http://omrpublic.iea.org. 
2 This view is shared by Y. Wang (1999: 227).

3 Between 1950 and 1961, China relied heavily on the Soviet Union and Romania for crude oil and petroleum products. Oil imports fell drastically after 1963 (Cheng 1976: 158). It is therefore quite fair to argue that oil dependence has been a security issue since the founding of the People's Republic.

4 The data are drawn from the Almanac of China's Foreign Economic Relations and Trade 1994/95: 681, 700, 701; and Zhongguo tongji nianjian 1996: 206; 2004: $277,724,726$. The net imports of oil in 2003 rose to 97.41 million tonnes in 2003 (Zhongguo tongji nianjian 2004: 724, 726), but Chinese official data on Chinese oil consumption are not yet available in Zhongguo tongji nianjian 2004. If data from British Petroleum (2004: 10) are used, the ratio was 35.4 per cent.

5 Its output fell to 48.4 million tonnes in 2003 and further to 46.4 million tonnes in 2004 (Cheng and Ng 2005).

6 See Energy Information Agency of the US Government, Annual Energy Review 2003, 'Crude oil prices by selected type, 1970-2004'; available at http://www.eia.doe.gov/emeu/aer/txt/ptb1107.html.

7 OPEC has reached a consensus on an upward revision of the price band (for an OPEC basket of seven benchmark crudes) to US\$28-32 a barrel or US\$26-34 a barrel from US\$22-28 a barrel. But the cartel has yet to agree on when to move its price range higher (IHT 2004c). Oil prices surged to the nominal record high US\$55.57 a barrel on the New York Mercantile Exchange on October 25, 2004; Brent crude oil prices hit US\$51.65 on the International Petroleum Exchange on October 22, 2004 (Reuters 2004b).

8 China's reliance on Oman for oil is partly due to a technical factor. Chinese refineries can readily process sweet (low in sulphur content) oil from Oman, but have difficulty in using sour (high in sulphur content) crude from other Middle East oil-producing countries (Downs 2000: 32; International Energy Agency 2000: 51). Information about the principal sources of China's imports of crude oil is available at the China Commerce Yearbook, formerly known as Yearbook of China's Foreign Economic Relations and Trade.

9 However, whereas the Organization of Petroleum Exporting Countries (OPEC) now accounts for only 33 per cent of global oil production, the share is expected to rise to more than 50 per cent in 2030, as oilfields in non-OPEC oil-producing countries are declining in output (Mouawad 2005).

10 Africa has emerged as a major source of China's imported crude oil. Angola, Sudan, Congo and Equatorial Guinea provided China with about 23 per cent of its oil imports - by pecuniary value - in 2003. In January and February 2004 Chinese President Hu Jintao paid visits to three oil-rich countries in the continent Egypt, Gabon and Algeria - as part of China's global oil diplomacy (Ching 2004). However, the continent may not be a reliable source of oil, as African oil like the Arab one has also to be delivered to China by sea. The region is also plagued by long-lasting civil wars.

11 In the year crude oil imports from the two countries accounted for only 6.66 per cent of China's total crude oil imports by value (China Commerce Yearbook 2004: 636-7).

12 The implications of energy (in)dependence on a country's freedom to practise its foreign policy are briefly discussed in Mitchell et al. (2001: 200-1).

13 Zha Daojiong, an energy specialist at Renmin University of China, is sceptical about the size of proven oil reserves in Kazakhstan. CNPC's investment in the country is disappointing. In five years it found less than 1 million tonnes of oil in the country (O'Neill 2004).

14 An estimate says that up to 300,000 Chinese are in Kazakhstan which has a population of some 14 million. The decision of relocate the capital of the country 
to Astana from Almaty in 1997 was partly attributable to the intention to be further away from China (Economist Newspaper 2004c).

15 According to the Chinese account, it was Russia which initiated the project (Zhongguo guojia dili [Beijing], December 2004: 69).

16 Subsequent to Koizumi's visit to Russia in January 2003, major Japanese political leaders, including Foreign Minister Yoriko Kawaguchi and former Prime Minister Yoshiro Mori, paid visits to Moscow to lobby for the Pacific route (Yomiuri 2003).

17 Putin was quoted as saying that it was possible that laying a pipeline across China might be quicker and cheaper, but it was vital for Russia to remember the importance of developing eastern Siberia and the Russian Far East and to tap natural resources in the region so as to be able to connect with the whole world via the Pacific Ocean (Gorst 2003c).

18 In early 2003, Japan attached a condition to the offer of the loan. It was that the Russian government would provide a guarantee for future repayment of the loan. But Russia, which had already had huge outstanding foreign debts, was reluctant to accept the condition-attached loan offer (Kyodo 2003a, 2003c).

19 The two countries also could not seal an agreement on a proposed gas pipeline that would deliver natural gas from the Kovykta field in eastern Siberia to China and South Korea. It was expected that even if the discussion of the oil pipeline had been stalled, Russia would have given the gas pipeline the green light (Buckley 2004). The plan was accepted by the Russian government in April 2005 (The Economist 2005).

20 Transneft had reportedly proposed to the Russian government that a 4,368-km pipeline from Taishet to Nakhodka be constructed in two stages. Under the first stage, a pipeline would be built from Taishet to Skovorodino, which is only $70 \mathrm{~km}$ north from the border between Russia and China. From Skovorodino, a spur to China would be built. Under the second stage a pipeline would be constructed from Skovorodino to the Pacific coast. The two lines would be able to deliver 1.6 million barrels per day (Sharushkina 2004).

21 In 1980, 37 per cent of the oil the United States consumed was imported. The share increased to 54 per cent in 2002 and is projected to rise to 70 per cent in 2025 (Mouawad 2004).

22 The break-up of the private oil company Yukos testified to Putin's intention. Yuganskneftegaz, the largest subsidiary of Yukos, was sold to Baikal Finans Group, a mystery company, in December 2004 for US\$9.35 billion at auction. Shortly after the auction, the state-owned Rosneft, chaired by Igor Sechin, the deputy chief of Putin's administration, announced that it would acquire Baikal Finans Group. Rosneft was originally scheduled to merge in January 2005 with Gazprom, the natural gas monopoly in the country. Putin later defended the deals, saying that the state was protecting its interests (Arvedlund and Romero 2004; SCMP 2004h). To shield Gazprom and Rosneft from litigation by Yukos's shareholders, the Kremlin said later that the controlling stake in Yuganskneftegaz would be transferred to the newly created state-owned firm and would not be part of the merger between Rosneft and Gazprom (Myers 2004). The merger plan was scrapped in May 2005 partly because of a raw between the two companies over the terms of the merger (Gorst 2005; White 2005).

23 Oil independence was an issue in the 2004 US presidential election campaign. John Kerry, the Democratic nominee, unveiled an energy plan, in which he called for freeing the country from reliance on oil from the Persian Gulf (Banerjee 2004; Ivanovich 2004). Klare (2004) discusses the perils of the US dependence of imported oil.

24 Yukos announced on September 20, 2004, days ahead of the visit to Moscow by Chinese Premier Wen Jiabao that, due to its inability to prepay the export duties 
and transport fees, it would suspend part of its oil deliveries by rail to China's CNPC between September 28 and the end of the year. The amount of oil involved would be about 1 million tonnes. It was resolved only after CNPC agreed to pay the shipment cost for October in advance (IHT 2004d; SCMP 2004b; Shi 2004a; Ta Kung Pao, September 24, 2004: A2; Tan and Teagarden 2004).

25 China later did not insist on raising the prices of natural gas. Instead, it asked for a preferential price for the gas imported to China before Russia's accession to the WTO (21 shiji jingji baodao, September 23, 2004: 6). Victor Khristenko, Russian minister of industry and energy, emphatically pointed out that there was no connection between Russia remaining undecided on the Daqing pipeline and the fact that the two governments did not sign a protocol on Russia's entry to the WTO when Wen Jiabao visited Moscow in September 2004. The accord was signed by the two countries' presidents during the visit by Vladimir Putin to China in October 2004 (Prime-TASS 2004b; SCMP 2004e).

26 It is interesting to note that Wen Jiabo reiterated in Moscow China's pledge that it will never seek hegemony. Wen told Russian business leaders that 'China will never seek hegemony, even when [it] becomes strong. China is for Russia a country that can be trusted and counted on. [China and Russia] have a duty to be friendly neighbours' (IHT 2004e). However, in commenting on the RussianJapanese rapprochment, Toshiyuki Shikata, a defence analyst at Japan's Teikyo University, was quoted as saying that rapprochement 'as long as Japan and Russia are in cooperation, China would not be able to move against us' (Brooke 2005).

27 A Russian source, however, reported that during a meeting of the RussianChinese subcommission for cooperation in energy held on August 25-26, 2004, in Beijing, Victor Khristenko revealed that Russia could export only 8.6 million tonnes of crude oil to China in 2005 and the supplies could not be increased to 15 million tonnes a year prior to 2010. Consequently a draft five-year agreement entitled 'On broadening the Chinese-Russian trade in crude oil', proposed by China, was not signed in the bilateral meeting (WPS Russian Media Monitoring Agency 2004a).

28 The contract was signed in November 2004 (Shi 2004c).

29 See Calabrese (1998) for a study of Sino-Gulf energy linkages in the 1990s. China has developed ties with the Gulf states in the upstream and downstream sectors by not only importing crude oil from them but also allowing Gulf oil companies to develop China's domestic refineries and petrochemical facilities.

30 On this point see also Calabrese (1998) and Jaffe and Lewis (2002).

31 See Drifte (2004) for a study of Japan's Eurasian diplomacy.

32 According to Robert Jervis (1978: 169), in an anarchic international system a security dilemma exists when 'many of the means by which a state tries to increase its security decrease the security of others'.

33 A Japanese government survey found that natural-gas exploration in two fields in the East China Sea would probably affect fossil resources in Japan's exclusive economic zone (SCMP 2005d).

34 The Philippines stressed that the agreement on scientific research did not indicate any change in the sovereignty claims to the Spratly Islands. The Chinese Foreign Ministry did not mention the pact in its official report on Arroyo's visit (Dickie and Landingin 2004). Shortly after their President's visit to China, Philippine officials arranged for a regional meeting with other claimant countries, but they refused to disclose the details of the agreement (FEER 2004b).

35 Manmohan Singh said, 'I find China ahead of us in planning for the future in the field of energy security. We can no longer be complacent and must learn to think strategically, to think ahead and to act swiftly and decisively' (Bradsher 2005; Ghosh 2005). 
36 Examples include the third ministerial meeting of the Asia Cooperation Dialogue (ACD) forum in Qingdao in June 2004 and the third International Conference of Asian Political Parties (ICAPP) in Beijing in September 2004. At the end of the ACD meeting, a Qingdao Initiative was issued. The Initiative, drafted by China, attaches much importance to energy cooperation among the twenty-two member countries. The Beijing Declaration issued at the closing ceremony of ICAPP calls for cooperation in energy among countries in Asia (China Daily 2004; $\mathrm{Hu} 2004$; Wiest 2004b). Wu Lei (2003: 253-6), a Chinese energy strategist, also calls on China to set up an East Asian Energy Organization (EAEO) to address its energy security. Also see Andrews-Speed et al. (2002: 82-9) and Dannreuther (2003) for succinct discussions of the prospects of energy cooperation in the Asia-Pacific region.

\section{References}

AFP (2004a) 'Russia close to picking Japan over China for oil pipeline route', Agence France-Presse, February 20.

- (2004b) 'China, Gulf Cooperation Council negotiating free trade pact', Agence France-Presse, July 5.

(2004c) 'Vietnam hits out at China, Philippines over Spratly oil plans', Agence France-Presse, September 9.

(2004d) 'Russia has decided on oil pipeline route to Pacific: Tokyo ambassador', Agence France-Presse, September 24.

(2004e) 'India chasing China in Asian superpower rivalry for West Africa oil stakes', Agence France-Presse, October 15.

(2004f) 'Japan to build marine survey ship amid gas field dispute with China', Agence France-Presse, December 14.

(2004g) 'Russia orders oil pipeline to Pacific', Agence France-Presse, December 31.

AKIpress (2004) 'Expert: China should be cautious over Japan's moves in Central Asia', AKIpress (Kyrgyzstan), September 2.

Andrews-Speed, P., Liao, X. and Dannreuther, R. (2002) The Strategic Implications of China's Energy Needs, Adelphi Paper 346. London: International Institute for Strategic Studies.

Arvedlund, E. E. and Mouawad, J. (2004) 'Yukos sale deepens investor doubts', New York Times, December 21 and Romero, S. (2004) 'State company buys winner in Yukos deal', New York Times, December 23.

Banerjee, N. (2004) 'Kerry goal of U.S. independence on oil divides advisers', New York Times, August 7.

BBC (2003) 'Chinese companies interested in Iran oilfield tender', BBC Monitoring Asia Pacific, December 1.

BBC News (1998a) 'Kazakhstan and China to build oil pipeline', May 14; available at http://news6.thdo.bbc.co.uk/hi/english/world/asia-pacific/newsid_93000/ 93976.stm.

(1998b) 'Turkmen president in China', August 31; available at http://news.bbc.co.uk/hi/english/world/asia-pacific/newsid_161000/161719.stm. (1999) 'Kazakh-Chinese pipeline on hold', July 3; available at http://www.bbc.co.uk/hi/english/world/asia-pacific/newsid_385000/385305.stm. (2004a) 'Japan signs huge Iranian oil deal', February 19; available at http://news.bbc.co.uk/go/pr/fr/-/2/hi/asia-pacific/3499155.stm.

(2004b) 'China pressures Putin on pipeline', October 15; available at http://news.bbc.co.uk/1/hi/world/asia-pacific/3746444.stm. 
Becker, J. (2001) 'Chinese caught up in tides of change', South China Morning Post, October 15.

- (2004) 'China fights UN sanctions on Sudan to safeguard oil', The Independent, October 15.

Belgrave, R., Ebinger, C. K. and Okino, H. (eds) (1987) Energy Security to 2000, Aldershot: Gower.

Bellaby, M. D. (2003) 'Russia looks east to find market for oil', Associated Press, March 12; available at http://www.washingtonpost.com/wpdyn/articles/A16338-2003Mar12.html.

Bezlova, A. (2003) 'China: Russia's second thoughts slow plans to vary oil sources', Inter Press Service, September 26.

Bhadrakumar, M. K. (2005) 'India finds a \$40bn friend in Iran', Asia Times Online, January 11; available at http://www.atimes.com/atimes/South_Asia/ GA11Df07.html.

Blagov, S. (2004a) 'Russia tangles with Japan and China', Asia Times Online, September 1; available at http://www.atimes.com/atimes/Central_Asia/ FI01Ag01.html.

_ (2004b) 'China's Russian pipe dream', Asia Times Online, September 28; available at http://www.atimes.com/atimes/Central_Asia/FI28Ag01. html.

- (2004c) 'Mystery shrouds auction of Yukos unit', Asia Times Online, December 21; available at http://www.atimes.com/atimes/Central_Asia/FL21Ag01. html.

- (2005) 'Russia walks thin line between Japan and China', Asia Times Online, December 21; available at http://www.atimes.com/atimes/Central_Asia/ GA05Ag01.html.

Boyd, A. (2004) 'Oil worries lubricate South China Sea pact', Asia Times Online, September 4; available at http://www.atimes.com/atimes/China/ FI04Ad04.html.

Bozorgmehr, N., Dinmore, G. and Rahman, B. (2003) 'Russia and China bid for Iran oil field contract', Financial Times, July 10.

Bradsher, K. (2003a) 'Chinese company to buy stake in big Caspian oil field', New York Times, March 8.

- (2003b) 'China buys another piece of big Caspian Sea oil field', New York Times, March 12.

_ (2005) 'Alert to gains by China, India is making energy deals', New York Times, January 17.

Bransten, J. and Lelyveld, M. (2004) 'The dragon in Central Asia, Part 1: The hunt for friends, and oil', Asia Times Online, November 23; available at http://www.atimes.com/atimes/China/FK23Ad03.html.

British Petroleum (2004) BP Statistical Review of World Energy 2004. London: British Petroleum.

Brooke, J. (2004) 'Japan's new military focus: China and North Korea threats', New York Times, December 11.

- (2005) 'Quietly, Russia and Japan mend ties', International Herald Tribute, Hong Kong edition, January 11.

Browne, A., Bahree, P., Barta, P. and Varkin, J. (2005) 'Oil thirst may spawn Asian giants', Asian Wall Street Journal, January 10.

Buckley, C. (2004) 'Siberia-China pipeline plan remains in talking stage', New York Times, October 16.

Buckley, N. Gurrera, F., Marcelo, R. and Morrison, K. (2005) 'India looks to Russia and Iran for energy', Financial Times, January 8.

Burton, J. and Donnan, S. (2004a) 'US plan to guard Strait of Malacca not welcome', Financial Times, April 6. 
and Donnan, S. (2004b) 'Malacca Strait pirates will sail into choppier waters', Financial Times, July 21.

Buzan, B. (1991) People, States and Fear: An Agenda for International Security Studies in the Post-Cold War Era. New York: Harvester Wheatsheaf.

Cable, V. (1995) 'What is international economic security?', International Affairs 71(2): 305-24.

Calabrese, J. (1998) 'China and the Persian Gulf: energy and security', Middle East Journal 52(3): 351-66.

Chan, E. (2003) 'Sinopec to buy stake in Caspian Sea oil project', The Standard, March 12.

Chazan, G. and Robbins, C. A. (2004) 'With oil price at stake, Yukos finds support', Wall Street Journal, August 12.

Cheng, C. Y. (1976) China's Petroleum Industry: Output Growth and Export Potential, New York: Praeger.

(1982) China's Economic Development: Growth and Structural Change. Boulder, CO: Westview Press.

Cheng, W.-G. and Ng, L. (2005) 'PetroChina has jump in natural gas output', International Herald Tribute, Hong Kong edition, January 18.

China Daily (2004) 'Asian parties map future in Beijing', China Daily, September 6.

Ching, F. (2004) 'Oil pressure', South China Morning Post, February 11.

Dannreuther, R. (2003) 'Asian security and China's energy needs', International Relations of the Asia-Pacific 3(2): 197-219.

Daragahi, B. (2005) 'China goes beyond oil in forging ties to Persian Gulf', New York Times, January 13.

Dickie, M. and Landingin, R. (2004) 'Oil pact marks new approach to disputes by China', Financial Times, September 3.

Dittmer, L. (2004) 'The emerging Northeast Asian regional order', in S. S. Kim, (ed.) The International Relations of Northeast Asia, Lanham, MD: Rowman \& Littlefield, pp. 331-62.

Dow Jones (2004) 'Singapore wants more help patrolling Malacca Straits', Dow Jones International News, December 9.

Downs, E. S. (2000) China's Quest for Energy Security, Santa Monica, CA: RAND. (2004) 'The Chinese energy security debate', China Quarterly, 177 (March): 21-38.

Drifte, R. (2004) 'Japan's Eurasian diplomacy: power politics, resource diplomacy or romanticism?' in S. Akiner, (ed.), The Caspian: Politics, Energy and Security, London: RoutledgeCurzon, pp. 278-94.

Economist Intelligence Unit (2004a) 'Saudi Arabia industry: oil majors on the sidelines', EIU Viewswire, January 28. (2004b) 'Kazakhstan economy: pick a pipeline', EIU Viewswire, July 19.

- (2004c) 'Asia at risk from high oil prices', EIU Viewswire, September 3.

Economist Newspaper (2004a) 'The price of oil: not so bad', The Economist, March 20-26.

(2004b) 'The oil wars: in the pipeline', The Economist, May 1-7.

(2004c) 'China and Central Asia: fear of the dragon', The Economist, November 13-19.

(2005) 'King Soloman's Pipes: Russian Oil', The Economist, May 7-13.

Eqbali, A. (2003) 'Japan asks Iran to extend talks deadline on Azadegan field', Platts Oilgram News 81(243), December 18.

(2004) 'Iran, Japan to continue talks on Azadegan', Platts Oilgram News 82(3), January 7.

FEER (2000) Asia Yearbook 2000, Hong Kong: Far Eastern Economic Review. - (2003) 'Crude pressure', Far Eastern Economic Review, February 13. 
(2004a) 'Island holiday, anyone? Vietnam's plan for arguing its claim in the disputed Spratly Islands', Far Eastern Economic Review, September 9. (2004b) 'Arroyo strikes a Spratlys deal with China', Far Eastern Economic Review, September 16.

Feng, S. and Xiang, L. (eds) (2004) Pu-jin waijiao. [Putin's Diplomacy], Shanghai: Shanghai renmin chubanshe.

Galloway, C. (2003) 'War in Iraq highlights energy supply concern', South China Morning Post, March 27.

Ghosh, S. (2005) 'PM cites China: oil PSUs can do with new look, compete abroad', Indian Express, January 17.

Gill, B. and Oresman, M. (2003) China's New Journey to the West: China's Emergence in Central Asia and Implications for U.S. Interests, Washington, DC: CSIS Press.

Gismatullin, E. (2004) 'Russia names preferred pipeline company', International Herald Tribute, Hong Kong edition, February 23.

— and Lim, L. M. (2003) 'Japan offers Russia \$7 billion in loans for pipeline', International Herald Tribute, Hong Kong edition, October 13.

Gorst, I. (2003a) 'One Far East oil pipeline needed: Rosneft', Platts Oilgram News 81(48), March 12.

- (2003b) 'Russia delays decision on routing Far East oil pipeline', Platts Oilgram News 81(50), March 14.

_ (2003c) 'Russia prefers pipeline to Japan rather than China', Platts Oilgram News 81(104), June 2.

- (2003d) 'Kazakhstan looks to diversify into China', Platts Oilgram News 81(108), June 6.

- (2005) 'Gazprom Rosneft plan adrift', Financial Times, May 4.

Hsieh, D. (2003) 'Bad news for China's oil pipeline plans', Strait Times, November 6.

$\mathrm{Hu}, \mathrm{Q}$. (2003) 'Nation wins oil pipeline agreement', China Daily, May 29. (2004) 'New joint energy strategy launched', China Daily, June 23.

Huband, M. and Wallis, W. (2004) 'Al-Qaeda militants renew threat to attack Saudi oil installations', Financial Times, December 20.

Hutzler, C. (2003) 'China's Hu to meet G-8 leaders', Asian Wall Street Journal, May 22.

IHT (2002) 'Russia nets \$1.9 billion in oil company sale', International Herald Tribute, Hong Kong edition, December 19.

- (2004a) 'PetroChina to explore in Spratly chain', International Herald Tribute, Hong Kong edition, July 7.

--. (2004b) 'Asian nations join to protect vital oil line', International Herald Tribute, Hong Kong edition, July 21.

- (2004c) 'OPEC official reports unity on higher price target', International Herald Tribute, Hong Kong edition, September 10.

(2004d) 'China calls on Yukos to keep its oil promise', International Herald Tribute, Hong Kong edition, September 22.

(2004e) 'Chinese leader meets with Russians on oil', International Herald Tribute, Hong Kong edition, September 25-26.

(2005) 'Russia welcomes India as possible oil partner', International Herald Tribute, online edition, February 23; available at http://www.iht. com/articles/2005/02/22/business/rusoil.html.

Interfax Information Services (2003) 'CNPC bought state-owned stake in CNPCAktobemunaigaz - Kazakh President', Interfax China Business News, June 6.

International Energy Agency (2000) China's Worldwide Quest for Energy Security. Paris: IEA/OECD.

Ivanovich, D. (2004) 'Backing off from Saudi crude', Houston Chronicle, August 7. 
Jack, A. and Pilling, D. (2003) 'Oil fuels Japan's drive to bring a thaw to relations with Russia', Financial Times, January 10.

_ and Rahman, B. (2003) 'Japan to push case for Siberia-Pacific pipeline', Financial Times, March 5.

— Stern, D. and Buchan, D. (2003) 'Struggle looms over rival oil pipeline routes from Siberia to the east', Financial Times, January 11.

Jaffe, A. M. and Lewis, S. W. (2002) 'Beijing's oil diplomacy', Survival 44(1): 115134.

Jakarta Post (2004) 'Japan offers to help secure Malacca Strait', Jakarta Post, December 17.

Jervis, R. (1978) 'Cooperation under the security dilemma', World Politics 30(2): $167-214$.

Jiang, Z. (2002) 'Build a well-off society in an all-round way and create a new situation in building socialism with Chinese characteristics I-III: report to the 16th National Congress of the Communist Party of China on November 8, 2002', Beijing Review, November 28, December 5 and 12.

Klare, M. T. (2001) Resource Wars: The New Landscape of Global Conflict. New York: Metropolitan Books.

_ (2004) Blood and Oil: The Dangers and Consequences of America's Growing Dependency on Imported Petroleum, New York: Metropolitan Books.

Kynge, J. (2004) 'China continues its quest for secure energy supplies with variety of sources as the aim', Financial Times, May 25.

Kyodo (2003a) 'Japan proposes loaning full sum for Russian oil pipeline', Kyodo News, April 16.

_ (2003b) 'Russia picks China in Siberia pipeline project', Kyodo News, April 18.

(2003c) 'Japan continues to lobby on Siberian pipeline project', Kyodo News, April 22.

_ (2004) 'Russia to sell China 15 mil. tons of crude by 2006', Kyodo News, August 31.

(2005) 'Russian ambassador says oil will first go to China, not Japan', Kyodo News, May 19.

Lague, D. (2002) 'The Russians are coming', Far Eastern Economic Review, June 20, p. 18.

Lam, W. W. L. (2001) 'China keeps watch on U.S. policy shifts', CNN.com, October 2. (2004) 'China's energy paranoia', Asian Wall Street Journal, July 30.

Lewis, L. (2003) 'Oil-thirsty China and Japan battle on drilling', The Times, July 21.

Lim. L.-M. (2003) 'Japan, China or both? Russia nears a decision on eastern pipeline', International Herald Tribute, Hong Kong edition, March 6.

— and Gismatullin, E. (2003) 'Russia rethinks China pipeline venture', International Herald Tribute, Hong Kong edition, September 18.

Liu, W. and Xie, Y. (2004) 'Sino-Iranian LNG deal in pipeline', China Daily, April 12.

Luce, E. and Morrison, K. (2005). 'India to open talks with Burma and Bangladesh on gas pipeline', Financial Times, January 11.

Ma, J. (2004) 'China backs push to avoid nuclear-linked sanctions', South China Morning Post, November 26.

Mai, T. (2003a) 'Pressure builds in pipeline talks', China Daily Business Weekly, September 30. (2003b) 'Oil giants to tap ocean resources', China Daily, November 13. (2004) 'No change in oil field bidding', China Daily, February 2.

Mallet, V. (2004) 'China is biggest oil consumer after US', Financial Times, January 21. 
Mitchell, J. Morita, K., Selley, N. and Stern, J. (2001) The New Economy of Oil: Impacts on Business, Geopolitics and Society, London: Royal Institute of International Affairs and Earthscan Publications.

Mouawad, J. (2004) 'New oil is elusive, and alarms ring', International Herald Tribute, Hong Kong edition, September 8.

- (2005) 'Production trends point to reliance an improve oil', New York Times, January 3.

Muramatsu, M. (2004) 'ASEAN moves to build oil stockpile', Nikkei Weekly, July 5.

Myers, S. L. (2004) 'China may be offered stake in Yukos subsidiary', New York Times, December 31.

Ng, E. (2003a) 'China Petro in fresh snub', South China Morning Post, May 14.

(2003b) 'CNPC buys out its partner in Kazakh venture for US\$150 m', South China Morning Post, June 7.

Nihon Keizai Shimbun (2003) 'Japan-China clashes imminent over overseas oil procurement', Nikkei Report, July 19.

_ (2004) 'Japan to build vessel to inspect gas fields in East China Sea', Nikkei Report, December 13.

- (2005) 'Japan Petroleum, Teikoku Oil to develop fields in East China Sea', Nikkei Report, January 16.

OGJ (1999) 'CNPC shelves China-Kazakhstan oil pipeline', Oil and Gas Journal 97(35), August 30.

(2000) 'Pipeline will move Siberian crude oil to China', Oil and Gas Journal 98(24), June 12.

_ (2004) 'ConocoPhillips reportedly eyeing Kremlin's Lukoil stake', Oil and Gas Journal 102(29), August 2.

Okada, Y. and Dobashi, F. (2003) 'Japan offers financing help for Russian oil export line', Platts Oilgram News 81(199), October 15.

Okubo, Y. (2004) 'Time government stood up to China over EEZ oil, gas reserves', Daily Yomiuri, July 10.

O'Neill, M. (2004) 'Russia struggles in the shadow of its powerful neighbour', South China Morning Post, July 5.

Ostrovsky, A. (2005) 'Russia looks East as West disappoints', Financial Times, January 3.

Pala, C. and Bradsher, K. (2003) 'Beijing and Caspian oil fields', New York Times, April 1.

Peel, Q. and Jack, A. (2003) 'Japan and Russia set to back pipeline', Financial Times, January 10.

Platts (2002a) 'China's CNPC applies to bid at Russian Slavneft sale', Platts Oilgram News 80(231), December 3.

- (2002b) 'Duma protest Chinese participation in Slavneft auction', Platts Oilgram News 80(241), December 17.

(2003a) 'Iran, tired of waiting on Japanese group, invites others to Azadegan talks', Platts Oilgram News. 81(182), August 28.

- (2003b) 'No decision on routing of Russia 1st east oil export line till 04', Platts Commodity News, September 24.

- $(2003 \mathrm{c})$ 'ChevronTexaco sells 65\% stake in Kazakh field to CNPC', Platts Oilgram News 81(203), October 21.

- (2003d) 'Russian Pacific oil pipeline won't happen for 5-7 years - Kasyanov', Platts Commodity News, December 16.

Prime-TASS (2004a) 'Russia to consider Daqing pipeline after Taishet-Nakhodka study', Prime-TASS Energy Service, September 24.

(2004b) 'Khristenko says experts to decide on Russia-Daqing pipeline Jan', Prime-TASS Energy Service, September 24. 
Raff, A. (2003) 'Russia's Yukos signs big deals on oil for China', Asian Wall Street Journal, May 29.

Rahman, B. and Jack, A. (2003) 'Japan offers Russia \$7bn to build oil pipe', Financial Times, October 14.

Reuters (2003a) 'China, Philippines welcome joint use of Spratlys', Reuters News, August 31.

(2003b) 'Philippines, China agree to explore oil and gas', Reuters News, November 10.

(2004a) 'China criticizes Vietnam over oil bids for Spratlys', Reuters News, October 20.

(2004b) 'NYMEX crude climbs to new high on Norway threat', Reuters News, October 25.

Richardson, M. (2004a) 'Oh, what nations will do for oil', South China Morning Post, March 5.

- (2004b) 'The treasure islands of Southeast Asia', South China Morning Post, May 28.

(2004c) 'Beijing's burning quest for oil security', South China Morning Post, August 6.

(2004d) 'An axis of energy?', 'South China Morning Post, November 12.

Roberts, J. (2003) 'Kazakhstan-China pipeline plan expanded', Platts Oilgram News 81(104), June 2.

_ (2004) 'Will Kazakh oil follow the Silk Road to China?', Energy Economist, July 1.

Saigol, L. and Roberts, D. (2003) 'Partners move to block Chinese', Financial Times, May 10-11.

Salameh, M. (2001) 'A third oil crisis?' 'Survival 43(3): 129-44.

Sanchanta, M. (2004) 'Japan consortium seeks European partners', Financial Times, February 20.

SCMP (2001a) 'Beijing to buy Russian-made jet fighters', South China Morning Post, July 19.

_ (2001b) 'Siberia focus of pact',South China Morning Post, September 28. (2003a) 'Russia to decide soon on oil pipeline', South China Morning Post, March 7.

(2003b) 'Siberian oil pipeline link to supply Daqing', South China Morning Post, March 17.

(2003c) 'Russia chooses China over Japan for oil line', South China Morning Post, April 19.

(2003d) 'Russia and China in pledge on oil projects', South China Morning Post, May 28.

(2004a) 'Main Siberia-Pacific oil pipeline will bypass mainland', South China Morning Post, March 23.

(2004b) 'Yukos halts oil exports to the mainland', South China Morning Post, September 20.

(2004c) 'Wen sees rise in Russian energy links', South China Morning Post, September 22.

(2004d) 'Moscow still undecided on pipeline', South China Morning Post, September 25.

(2004e) 'Beijing to sign accord on Russia's WTO entry', South China Morning Post, September 25.

(2004f) 'Surging oil prices weigh on global growth', South China Morning Post, September 29.

(2004g) 'Putin team hints Japan will get oil pipeline', South China Morning Post, October 16. 
(2004h) 'Yukos asset purchase protects national interests, says Putin', South China Morning Post, December 24.

(2005a) 'China shunned as Russia decides on Pacific oil pipeline', South China Morning Post, January 1.

(2005b) 'China oil imports up 35pc', South China Morning Post, January 13.

(2005c) 'Firms seek rights to drill for oil', South China Morning Post, January 17.

(2005d) 'Survey adds fuel to row on gas fields', South China Morning Post, February 19.

(2005e) 'India eyes stakes in Russian oilfields', South China Morning Post, February 21.

(2005f) 'Russia gives not to China branch of Siberian pipeline', South China Morning Post, April 7.

Sharushkina, N. (2004) 'Putin orders decision on Pacific oil pipe', International Oil Daily, November 3.

Shi, T. (2004a) 'Wen puts energy needs at top of his Moscow agenda',South China Morning Post, September 24.

(2004b) 'Wen returns with deals in pocket', South China Morning Post, September 26.

- (2004c) 'Oil imports from Russia by rail set to increase', South China Morning Post, November 27.

Solovyov, D. (2003) 'Kazakhs plan China oil link to tap rising output', Reuters News, September 10.

Stares, P. B. (2000) 'Introduction and overview', in P. B. Stares, (ed.) Rethinking Energy Security in East Asia, Tokyo: Japan Center for International Exchange, pp. 19-41.

Starobin, P., Betton, C. and Crock, S. (2002) 'The next oil frontier', Business Week, Asian edition, May 27, pp. 42-49.

Takahashi, K. (2004) 'Gas and oil rivalry in the East China Sea', Asia Times Online, July 27; available at http://www.atimes.com/atimes/Japan/FG27Dh03.html.

Tan, S. (2004) 'China, Philippines agree to Spratlys seismic', International Oil Daily, September 3.

— and Teagarden, M. (2004) 'Yukos to cut China crude shipments due to financial woes', The Oil Daily, September 21.

Tschang, C. C. (2004) 'Build an oil pipeline from Myanmar to China', Strait Times, July 15.

Tyler, P. E. (2001) 'Kazakh leader urges Iran pipeline route', New York Times, December 10.

US-China Economic and Security Review Commission (2004) 2004 Report to Congress of the US-China Economic and Security Review Commission, Washington, DC: US Government Printing Office; available at http://www.uscc.gov/researchreports/2004/04annual_report.htm.

Wang, L. (2003) 'Oil pipeline compromise likely', China Daily, March 3.

Wang, Y. (ed.) (1999) Quanqiuhua shidai de guoji anquan ([International Security in the Age of Globalization]). Shanghai: Shanghai renmin chubanshe.

White, G. L., Larkin, J. and Singer, J. (2005) 'India seeks stake in Russia's Yugansk', Asian Wall Street Journal, January 12.

_ and Pottinger, M. (2005) 'Russia's Rosneft begins running main Yukos unit', Asian Wall Street Journal, January 3.

White, G. (2005) 'Kremlin cancels its plan to merge Gazprom, Rosneft', Wall Street Journal, May 18

Wiest, N. C. (2003) 'Russia puts US\$2.5b oil pipeline deal on hold', South China Morning Post, September 25.

(2004a) 'Beijing to tap into Spratlys gas deposit', South China Morning Post, May 14. 
(2004b) 'Region unites in pact enhancing energy security', South China Morning Post, June 23.

WPS Russian Media Monitoring Agency (2004a) 'Russia to increase oil supplies to China by railway', WPS: Russian Oil \& Gas Report, September 1.

(2004b) 'Russia left CNPC without oil', WPS: Russian Oil \& Gas Report, November 15.

Wright, R. (2004) 'Iran's new alliance with China could cost U.S. leverage', Washington Post, November 17.

WSJ (2004) 'Uzbekistan deal widens China's energy network', Wall Street Journal, June 17.

Wu, K. and Fesharaki, F. (2002) 'Managing Asia Pacific's energy dependence on the Middle East: is there a role for Central Asia', Asia Pacific Issues 60, (June): $1-8$.

Wu, L. (2003) Zhongguo shiyou anquan [China's Oil Security], Beijing: Zhongguo shehui kexue chubanshe.

Xiao, X. (2004) 'PetroChina eyes oil exploration in South China Sea', China Daily, July 6.

Xie, Y. (2003) 'Sinopec taps into Kazakhstan', China Daily, March 12.

(2004) 'Nation pins hopes on oil project with China', China Daily, March 23.

Xinhua (2004) 'China refuses to share offshore natural gas exploration information with Japan', Xinhua News Agency, September 7.

Yomiuri (2003) 'Government ups ante in Siberia oil race', Daily Yomiuri, July 11. (2004) 'Iran oil field deal expected in near future', Daily Yomiuri, February 19.

Zhang, K. (2004) 'China and Japan's oil rivalry unavoidable', China Daily, July 13.

Zhdannikov, D. (2003) 'Russia decision on China pipeline may take a year', Reuters News, September 25.

Zhu, Q. (2003) ‘A pipeline for prosperity', China Daily, September 26. 